U.S. Department

of Commeree

National Elireau

NESIR SE- 3312

of Standerds

January 1 '马e6

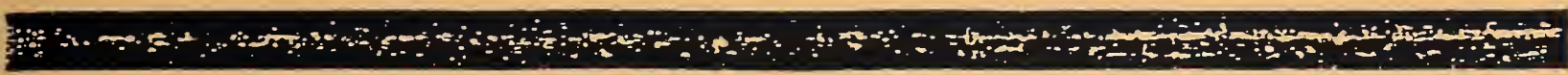

\title{
AN ARCHITECTURE FOR \\ DISTRIBUTED DATA MANAGEMENT \\ IN \\ COMPUTER INTEGRATED \\ MANUFACTURING
}

- FILE COPY

DO NOT REMMOY

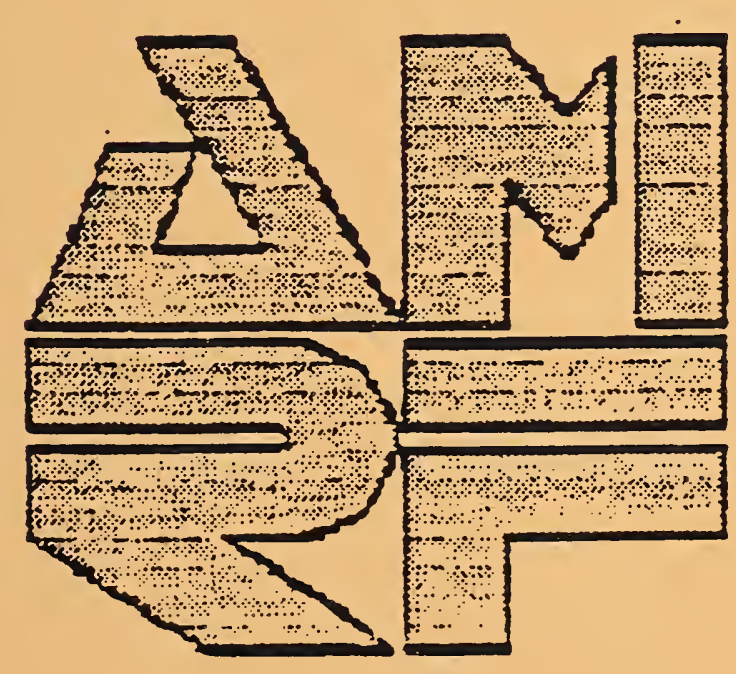





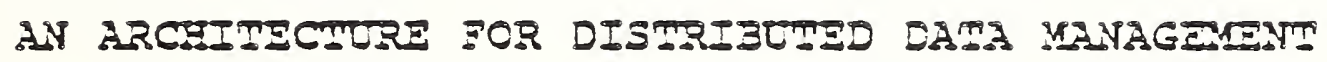
Is COMPUTER INTEGRATED MANUFACTURTYG Edwazd 3arlemeyer and Mazy Mitsterl*

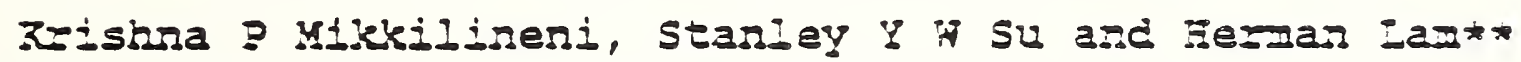

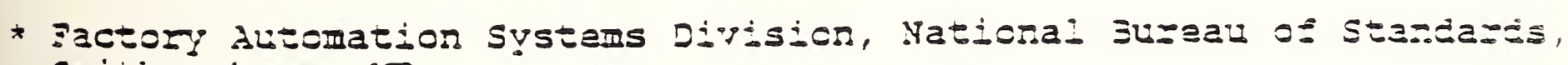
Gaithersbu=g, :D

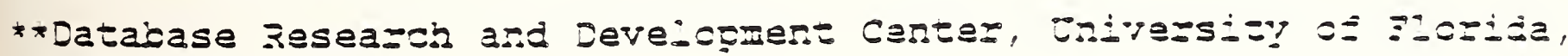
cainsvisile, $z$ 



\section{IMTRODUCTION}

Computer Integratad Manufacturing (CIM) includes activities for supporting, planning, and controlling the manufacture $\theta$ products. Our definition of a CIM system is one that is capaide of supporting the total marufacturing process, from specification wrough production, and retaining the information generaved wo: later aralysis of reuse. The objective of CIM is to ingrove wo aquisition and dissemination of manufacturing information asc thus, improve manufacturing effectiveness and resource utilizabion that enables an enterprise to compete economically.

At this time, computer-aided systems and lethods exist is support some manulacturing sunctions. Wewer methods such as tria: fitting of orders, net change plannirg and rough cut resousse plansing are expanding the capabilities of CIM [Rec32]. Most e: these systems and yethods bave been desigred and used to supect: isdividual masuracturing functions only. The result is a linised interaction among the different component functions of CrM. Gsisequenty, a totaly integzated yasusacturing systam does not ie: exist.

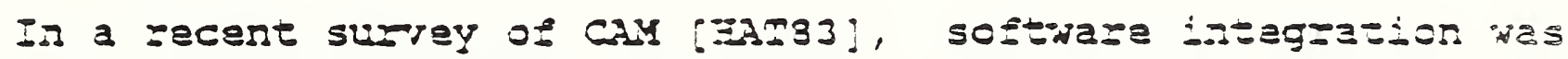
identified as the technolegy with be greatest gotential to pais CIM a reality. To zealize the benerits gromised by CiM, the fü:y irtegrated marufacturing system lust l) linis the activisias or the shop Sloor with he cesign, pianning, and ranuzacturing engiseering functions, 2 ) provide an accurace and limeiy foechack srom

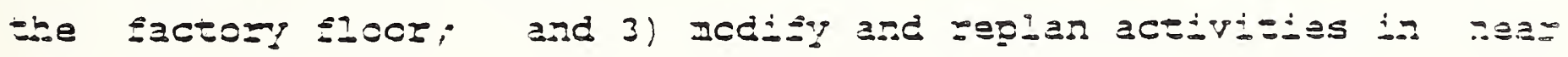


real-tine based or the actual seromance ierdback.

Cantral to the fully integrated namufacturiag systad is bis data admidistration system whose function is to manage the shasci data resources throughout the desigr, glansing and lanufactusing processes. The issues of representation, integration, and acministration of CaD/CHM data have been identilied as some of tab Iajor

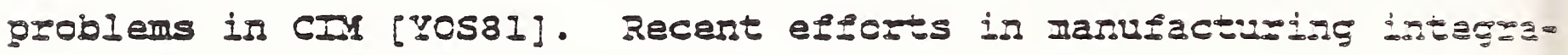

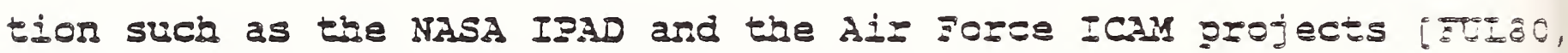
ICA79] baye stressed the importance of data management id bix by concentzatiog zesources or the study and development of dataisas management techuigues.

This paper presents a distributed database managenent sistas

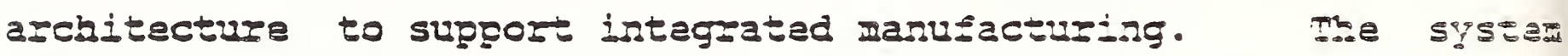

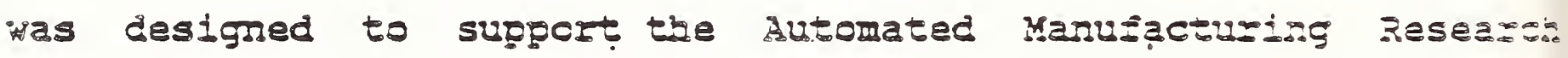

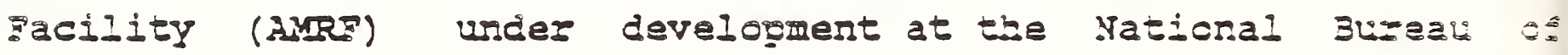

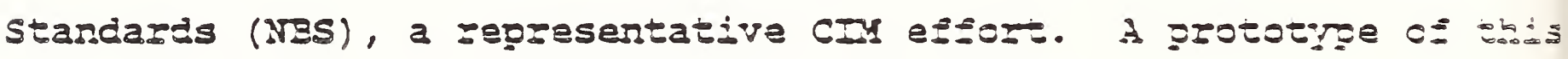
systam is under develecrment is that aciilizy.

The remainder of this section sumarizes the salient featumes of the lis project. In section 2 , we discuss tio unusia:

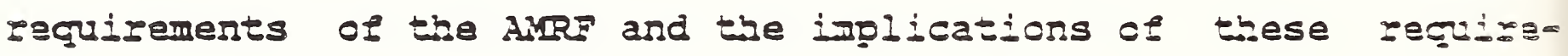
ments on the ranagement ol data ia a cif system. Section gresents the ovezall design of a carabase acministuation sysess arbitecture for CIX, evolired from our urderstarding c: loese requizements. In section 4, we descrije ia scue detzil tae Iaje medules of this system. Section 5 prosents vazicls scenazics o:

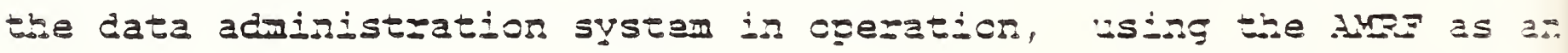

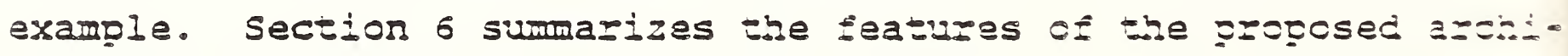


tecture, provides a status report ard indicatas ba disacticlo $\theta$

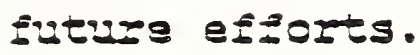

1.1 TIE AMRE AND ITS OBUECTIVES

The National Bureau of Standazds Automated Manufactuming Research Facility is being developed as a testbed for automate smaIl batch manufacturing [SIX82, MCL63!. It Hili be used se support experimentation in automated netrology ard jabsop

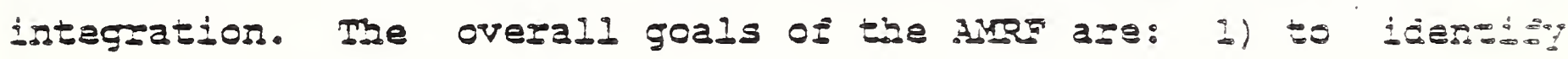
potential standazds and interface protscols for autcratac mas:üac turing, and 2) to futher measurament techrigues and develos

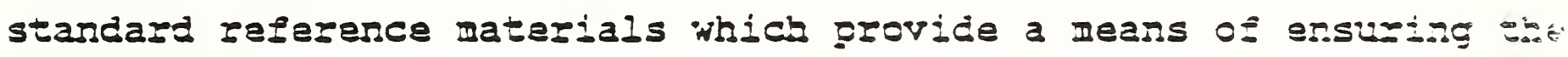
Ezacability of processes and products to rational siandazas.

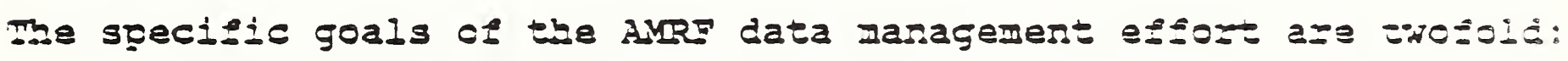
1) to support the data reeds el the AMRI, and 2) to ider.izy and prototype data management intarzace protscsis ibich are suivajie

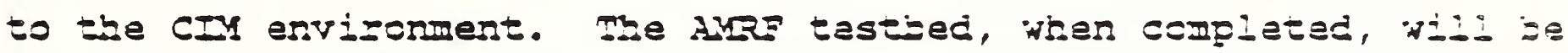
race available il seiected jesearch projects by the acacemia, industy, reseazch institutions, and other goverment agerciss.

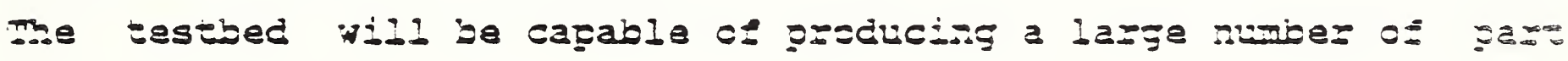

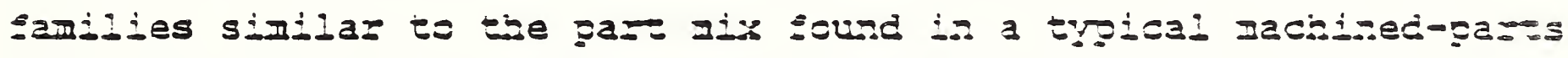

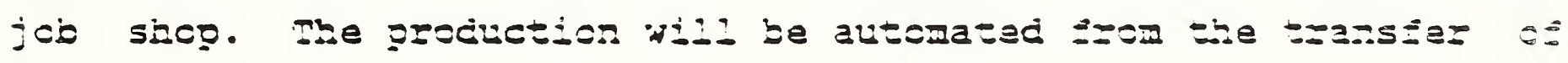

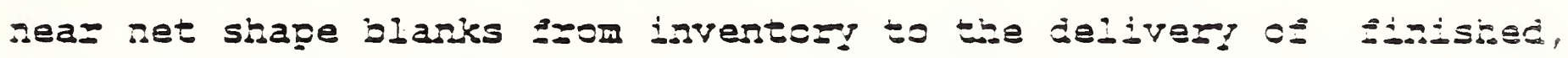
cleaned, and isspecsed sazes.

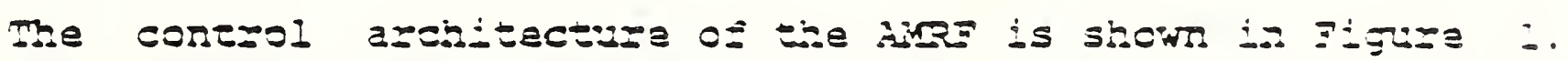

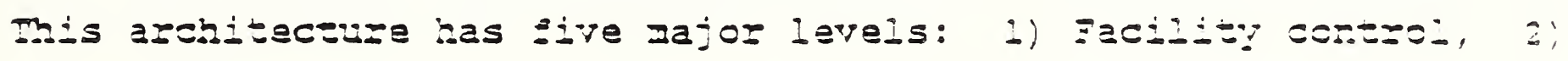

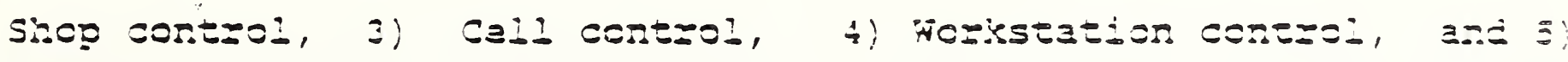

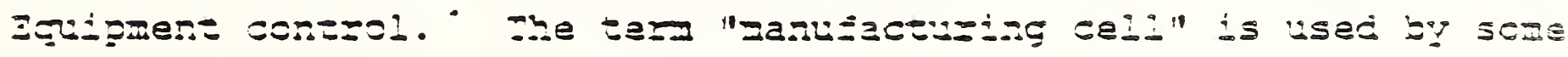


sexible manufacturing systems anc fixed automation applications to designate an eçuipment cluster, which the ARR identifies as "horkstation". The MUR architacture zeseryes the tarl "cain" sop the cortrol system coordirating workstatiens in part batch procuco tion. The tyoical worlestation in the AMRE is configured with a machine tool, an industrial robot, automated matszial tzassia: areas, and an intalligent workstation controllez, whose funcuin. is to ccordisate equipment level operations. The cortus aroki=

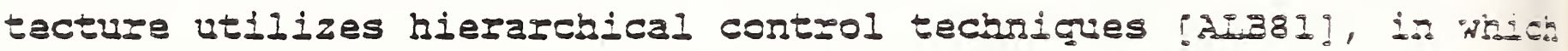
long range prociucticn goals are decorrosed at the faciqitig lovg. irto segruences of tasks, which are ther assigred to a suboringas control macule to manage. These tasks are fumber decomposed ask assigned to lower level control mccules; each cortrol medule cars

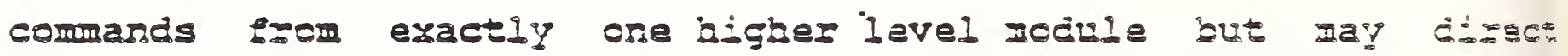

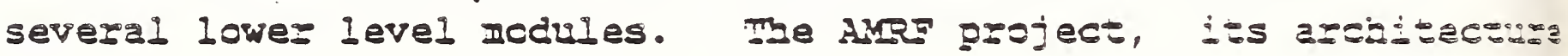

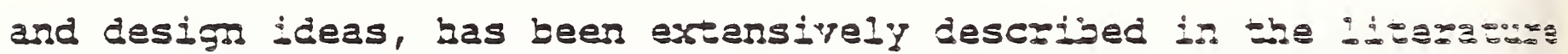

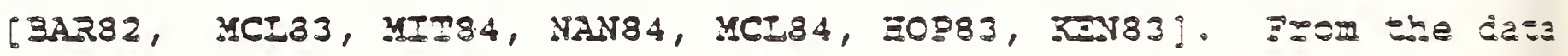
systems point of view, two chazactaristics distinguist tise aro: from other liexible marulacturiag systems: the ability of gis woristations to furction autonomously, and the expitcit separawisn oz contzol data s=om control algofithers. 


\section{DATABASE MANAGENENT REQUIREMENTS IY COMPUTER INTEGRAFE:}

\section{MAVETACTURIMG}

The design of a system to support the information recisideo ments of automated manufacturing is affected by the envisonment in which it must operate. The following reçuirements, whis sesm generally apelicable to any CIM system, bave been expressec :- bo development or the AMR tastbed:
a) integration of beterogenecus systems;
b) component systems witb different data management abilijitj
c) botb autonomous and integrated operation of subsystems;
d) Elexible narufacturing;
e) tire critical operations; and
f) use of acaptive control techniques.

The main surction of a database management system in this environment is to provide the compcrent systems with access to bis integrated database which cortains data necessagl to support the design, planning, manufacturing, assembly, isspecion, and sefice of products. It must also provide other davajase masagement

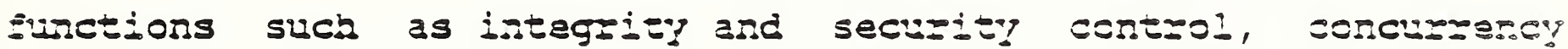

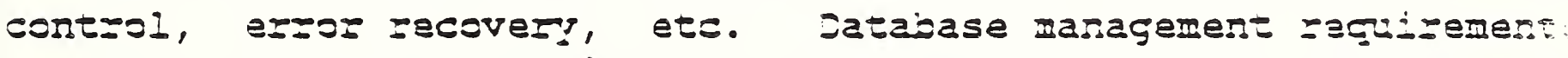
for CIM SOllow directy from the characteristics abcve and can be stated as soliows:

a) Integration of Betercgenecus systems: The somuling

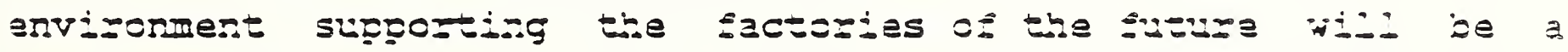

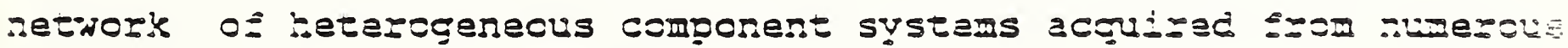

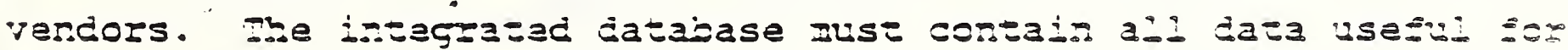


the control and management of the comporent systems and skcuid serve as a Hedium throvgh will the componest systems csmumicaps with one anotber. The software system inbicb madages tis integrated database should mask the differences iniseart i: accessing data in a hetregenous environment. A bigh level dats

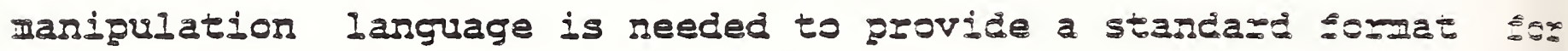

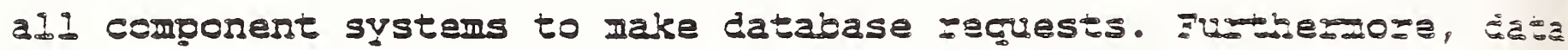

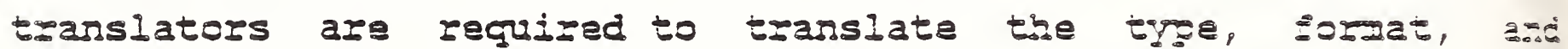
strictuse of the data intarchanged among the compenert sistas. comand translators are jeguind to trasslate the grezies gosed i: the common data manipulation langiage into the commans which can

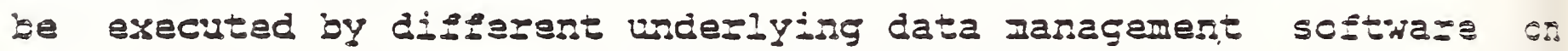
the comporeat systems.

b) Comporent Systems With Different Data Kanagement Caæai. lities: The component systams in as integrated factopg negrom

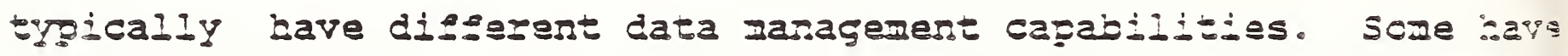
very cacable comercial database maragement systans, ibile etwas

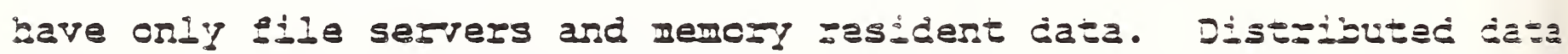
management soltwaze reeds to be instalied or selected compenerus

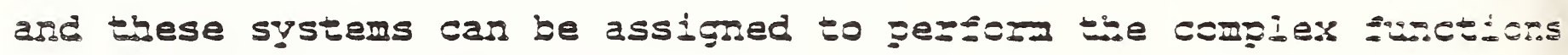

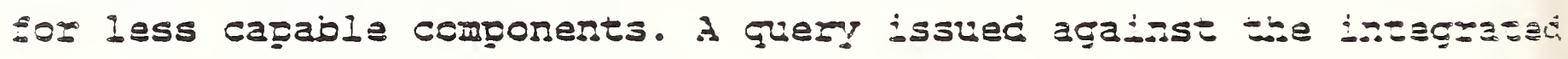
database urst be deccupcsed into database cperations ibici am

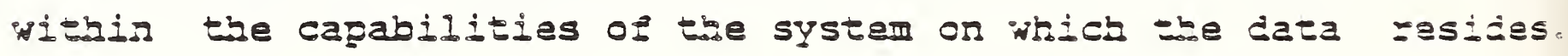
A defined set of zyinitive operations, a generalized lethed Es

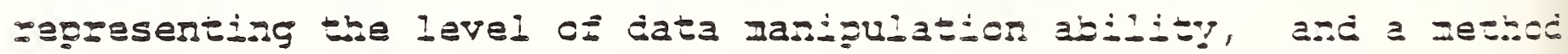
of assigring operations to more capable systems aze a-i neeced i:

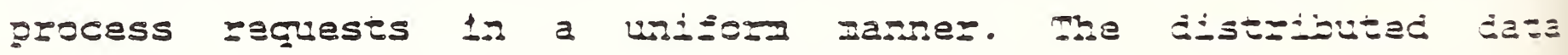




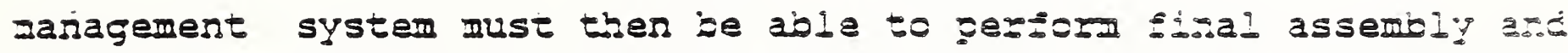
somattirg of the data letrieved fysm different comporent systams and deliver the result in the desized form.

c) Iocal Autonomy and Integrated cieraticn: Whenevez sein equipment or control software is intzoduced to bse facterl daba setwork, the control and data systoms must gyopide fer id

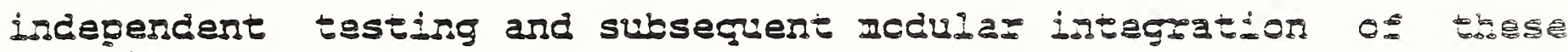

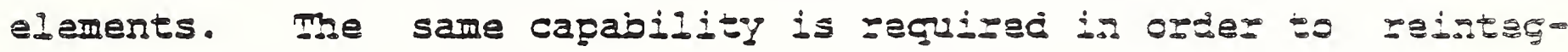
zate equipment which has been logicaliy removed fyom the setinozis for maintenasce or resit. Note that in the case of a jilly auseInted worlestation, the "independent" test reguiges a sepanasa integration of the systems within the workstation into an alusnorous system secarate from the idtegrated sactofl data syster, ard, more inpostantly, separate s=ol thie live production data. Ma dasa

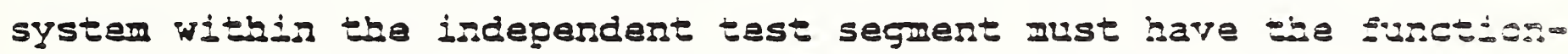
ality to acquize relevant segments ol he integrated dajaise and to manipurata this data. Theresore, as independent test segmen: Iust have at least one component system with yesident distaibusad

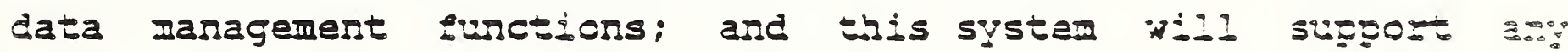

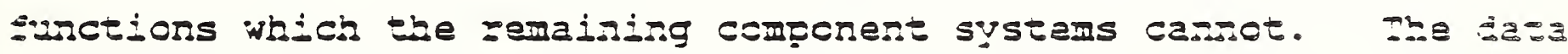

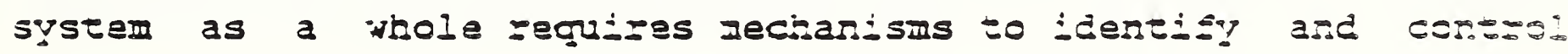
replication. Reintegration of somerly isolated comporents ings occur without disfuptiag crgoing production. Iocai dataisases am. data directories ust be zeconciied to fesolve he inconsistarcies

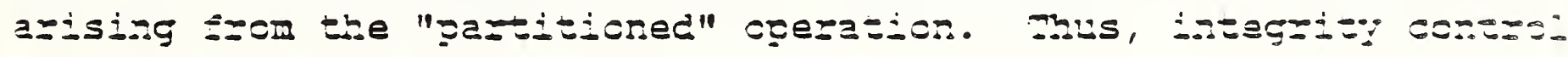

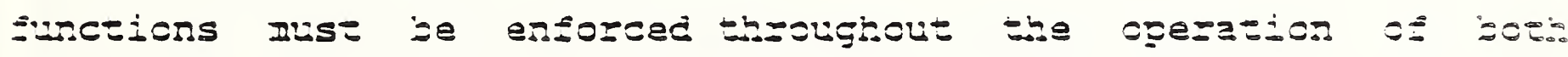

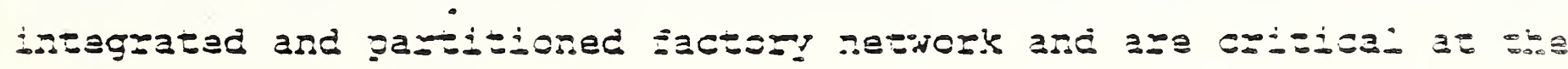


tire ol jeirtegration. To make this possiole, tor data syster Iust access and use configuration idformation duming its rogia: oceration.

d) Flexible Manufacturisg: Meetirg the objectives of laxids m2ภนfacturing, such as accommcdating urknow production demands, effective resource utilization and nodular expansion, affects the data management system id numercus ways. Moculas empasick dictates support of networls zeconfiguration, while effection resource utilization may dicteate suppost of dyramic consus: reconfiguration. From this we derive some precepes for tbe dab system. First, the database management system Ilst gIsvide data jo control processes in a completriy transpazert mansez, i. isdeperdent of the data lccaticr, the setwcrix configuration as. the curent control configuration. Seconc, data delivery gans should not be built disectly into tie cortul stractures of ibo comporent systams, but stould be constzucted by the datajast

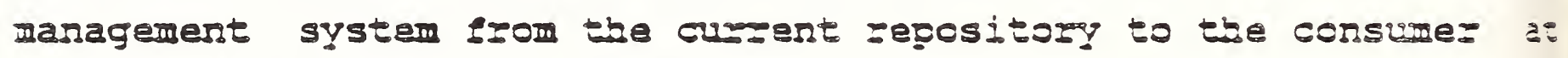
the tine pat consumeg's geçizement for that data entity is identified. misd, the database system should alisw frecuent and dyramic ugcates to the data difectorg which id past contaiss bos

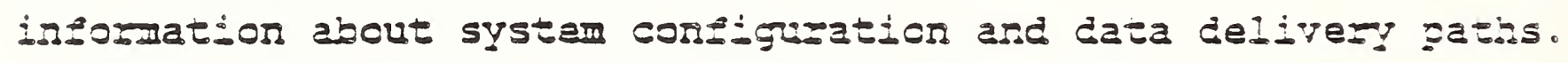

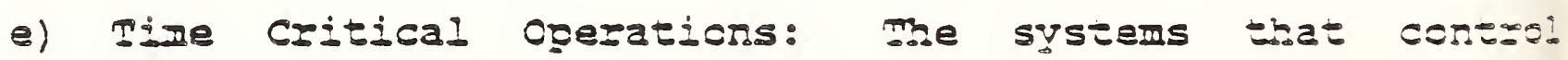
skotfloor equipment typically coezate id zeal-tine and have jise

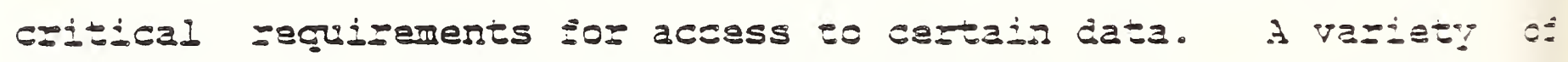
sensofy and seedback data originating in subczinares systems ay

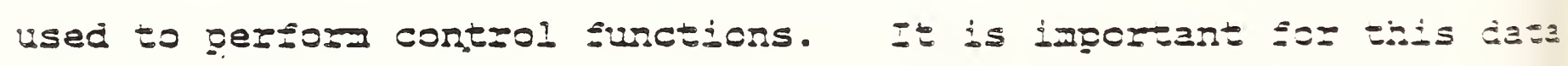




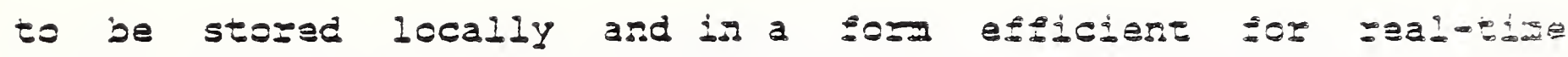
operaticn. There is a critical set of these data rasources inish must be shared and the time criticalitid will eftect the dectsions or bow to distributa this data. In database maragement tarss, bisis mears that:

- data urits may have to be rablicated szen ene componas: systam to asotber;

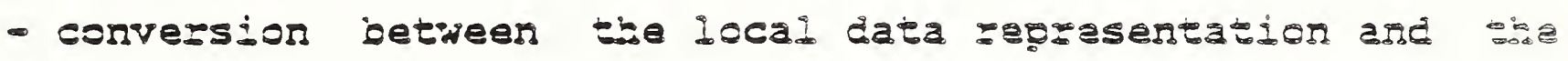
neutral data representation is recessary and frecuent; and

- a lecai data directory and some facility sor acsessing arid maintaining the global directorg must be grevided at eab componert system.

-) Adaptive control: The control system for integratod Mantfacturing. Iust be able to detect and zeace to failures and unexpected events. The database management system Iust be abie s.

- move data witb sufficient speed for bime-crivisa: operations,

- monitor the state of the data maragemene systam ard racove: f=sm a sailed data system component,

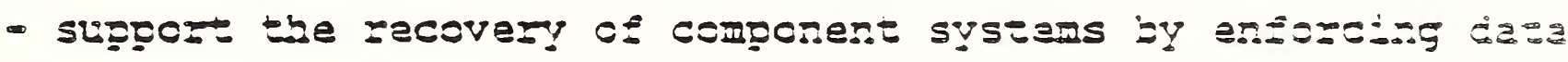
consistancy corstzaisis,

- aliow malfurctionirg componerts to be legically discen:nected, ever though they pay continue to demand jata sezpises, and - act as a systam resource to gachez and revain daza ajocu we integrasad operation for lataz araiysis. 


\section{THE DATA MODEL AND ARCEITECTURE OE TEE IYTEGRATED}

MANUFACIURIYG DATABASE ADMINISTRATION SYSIEN (IADAS)

In the CII environment, the existing databases aze already distributed across different component systems. MDAS supports an integrated database composed of physically distributed databases. The construction and maintainance of the intagrated database relies beavily on the data model used to define the data rasiding in the component systems.

3.1 A DATA HODEL FOR TIE INTEGRATED DATABASZ Te user racility which embodies the data recel wus: balance the conflicting critruia of simplicity, logical csmpleteress, and flexibility. It provides for the description os data definitions, interactions and mapoings of the distributed databases, the declaration of integrity ard security corstrainos, and the definition of access recquinements. The data nodel used in CDI must especially be able to supcort the complex CAD/CAM dasa tyges which are not reeded in business data zcdels and uust se able to maintain complex constraints and zelajionsisips. The dasa model selected for IMDAS is based upon the semantic Asscciasica Model (SAM\#) [SE83,SU85]. SAM\# is Iich is data semanties and contains a mumer of constuces for modelinge the ralationsidiss among the data fourd in engireering, busiress, scientisic anc statistical dataicases. The SMM* model contains severai samartid constructs to supcort the description of data sartitions,

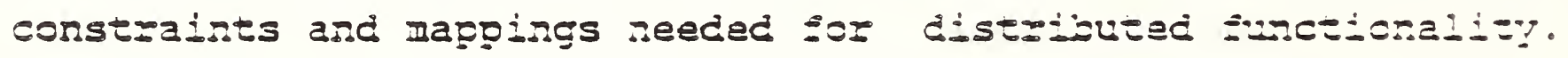

To describe the mappings berween tie legicaliy singie integrated database and the numerous physicaliy distribulect 
databases, three levels ol view definition aze suscorted by sa IMDAS. These views are: 1) global exterdal view, 2) gicial conceptual view, and 3) szagmentad view. A global exterael vigit defines a segment of the integratad dataise as seen by a siogla control process. It identifies the data entities and associatiers used by the contzol process. Mrez can be many gicial extaxa. views dafised for the vazious control grscesses. The gleda: conceptral view is the integration of all bhe external views and represents a comprised view of the factory database. The ifr: "global" is used to distinguish these views Exom the extexnal ar.d conceptual views defined in some component DEMSs. F̈agnented vîns represent glcbal conceptual data wich are shysicaily gartíicsed or replicatad across the component systems. They describe lis distzibution of the conceptual database; data witbia eaci congo rent system is represented as a distinct szagrented view. Iac:

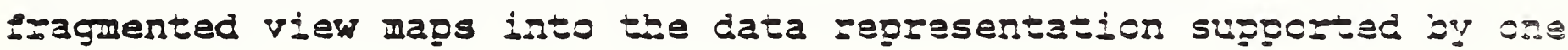

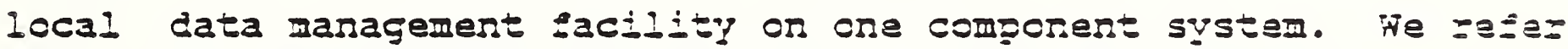
to the fragments of the glojal dataise wisto aze distributsa amcng the rodes id the system as sub-databases. The lalaticrisia ancrg tise different views is shows is Iigrae 2.

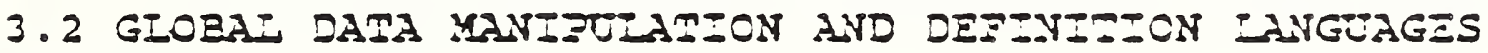

In the distributed darabase envisorment, a scurce sysas cbtains acsess to data residing on a tazget systam jy issuing a

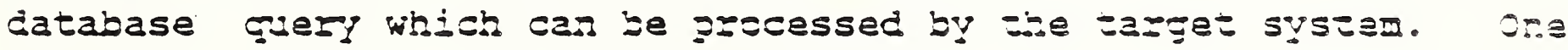

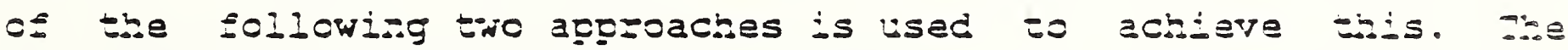

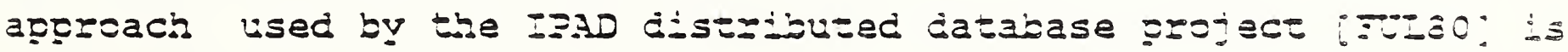

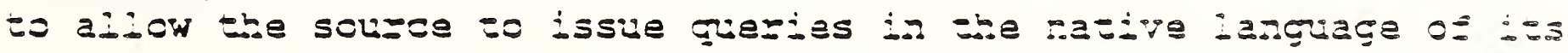


lccal DEMS. This systam then translates the guefy iats bhe language used by the target system and delivers the rssiling query to the target system. Ar alternative raquizas all csotzo! processes to use a comor global data manipulation larguage (GDM) to issue database queries, as in the ICAM IISS project lackil. The lirst aporoch is desigred to recover sigrificant irvestuents in applications develooment and training in the local data panisio lation language. But it reguires that every component system bave the support of some local database management system and tha: there is a direct correspondence jetween the semantics of all query languages is use. These assumptions are not vaild ia a

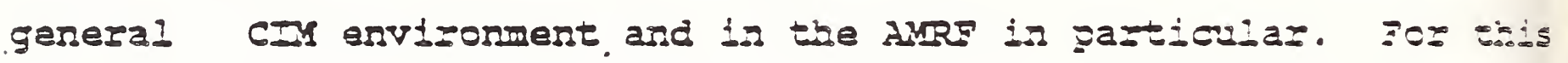

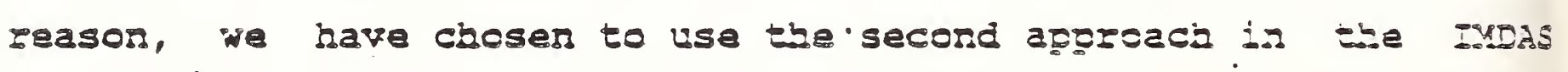
design. It not only eliziratas the singla-sourca-ro-mul=igia varget translators but also provides a comon guezl language ane bown semantics for all the component systems. The TMAS Gin [RRI85] bas been desigred to support the SAM* data lociel and is strongly based on the draft grocosed AisI standard darabase zan:viation language [ANS35].

The data model and the giobal data manijulation langsage will be discussed in more derail in subseguent papers.

3.3 DESIGH CONSIDERATIONS

There are tiNo basic distributed bavabase zanagemer: architectures: centzalized ard distrisuted. In he cers=a:ized azchitecture, a sirgle centual data administzation system hardies all of the contzol and data masagement functions. Data car is 
stored in either centralized or distributed locations but aid catabase requests are routed to a crintral control mocule. Fis: architecture is straightforward to develop and manage, and is being used is some partially automated factories. Perforarce of a centralized system depends on the number and activity level of the component systems competing for sertices. Centrainzed cortrol, however, is not suitable for extensive CIx systams because bia architecture does not meet the requinements such as procictabla serfice times for time-critical operations, and adaptive recovery. Moreover, the single point of failure of the central system iroud create a serious reliability groblem.

In the fully distributed architacture, every compcres: system has a data administration system which controls and parages the distributed execution of the data management requests issuad at that system and is capable of servicing pequests coming fys otber component systams. This architectura lakes the system as a whole more reliable and grovides each comenent system itis

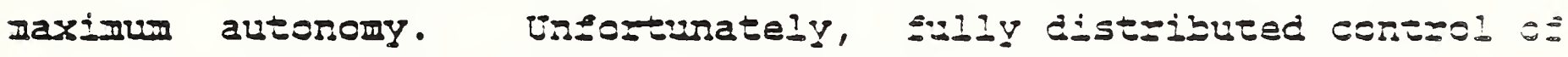
datalose integrity, concurrency, and recovezy is far zere difsicilt to achieve thas is certzalized corstori.

Most fully distributad database administration systoss ranage homogeneous business oriented davabases on iden=ina: computar hardware. As noted in the requizements discussion, a cark

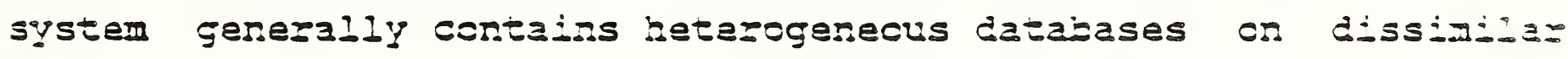

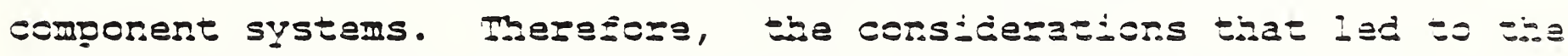

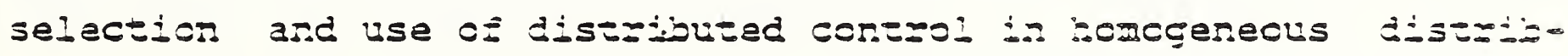
uted database management systems such as distzibuted pitsis, 
System R*, SDD-1, and POREL [HIL82, NEU84, CER84, ERAB2] are n.0 recessarily valid for the CIH enviroment. Imelementing a folly distributed database administration system on every betarcgereous componert system in a CIM environment is more difficult and eostiy than implementing it or many bomogeneous systems. Ard, a sigrista cant overded is involved in processing data using a fulgy distuia buted control stratrgy. This overbead is likaly to bave negative impact on the performance of real-time operations.

The IMDAS design pursues another cossibility; a bybrid architecture which is reither completely centralized nor sili! distributed. The architecture of the IMAAS intencis to capture tise advantages of both arabitectures. To achieve separabilitig, reliability and recoverability, the IMDAS minimizes certrainied finnctions and replicates the software which implements isese ริunctions. To achieve cost effactiveness, particulaziy on suali systems, INDAS does rot requiro full distributed data sermise capabilities or all comporents.

3.4 REIE REITIONSEIP BETHEEY IXIAS AHD CIY SUBSYSTEMS

The design of a distributed database management system fox CIM should consider the relationship among the three Iajor sosolox

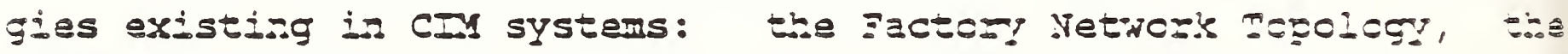
Control Topology, and the Distributad Database Kanagemen Tocology. We shall now discuss the gelationship betieen shese three topologies in the AMRF and the IMDAS azchitacture.

3.4.1 FACTORY NETHCRK TOFOICGI

The facsory netrozl provides the leans $0=$ communicanions among the component systems. hs iliustzared ir gigure 3 , jac 


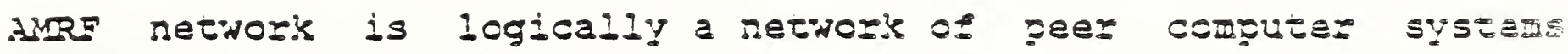
corrected to a comon bigh-speed bus. A sourdary is forced al bis workstations, wibis which bighly time-crisical teastic ccsus, Each workstation and its equipment are consected to one anotios through a privata workstation subsetwork. Eacb sulnetrork is consected to the main factorg retwork thuough a gateway. pha

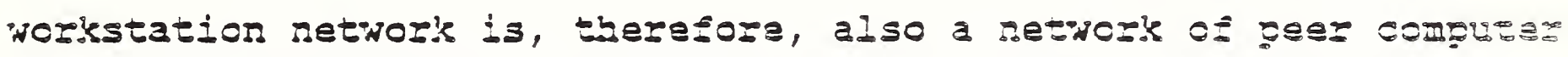
systams. Thus every system on the nethoyik cad access data fus or provide data to ary other systed on tie retincrk.

\section{4 .2 CONTROI TOPOIOGY}

Miere are several altemative contzol tosologies used i. Cal systems. In the ALRr, the varicus cortyol systems are geialod to. each other is a clear bierarchica! structuro. As depicsed is.

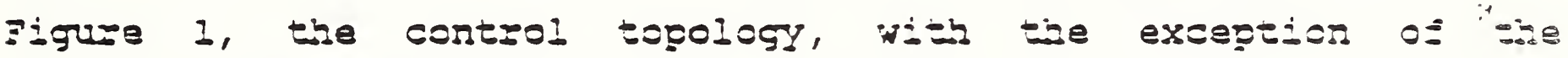

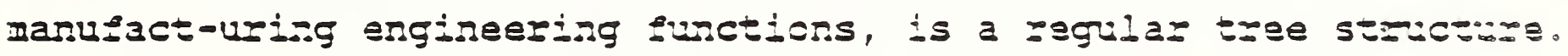
It is inpoztant to note that most data entar the system at ei-bas the top level of the control bierarchy of the sctsol. Al the sol,

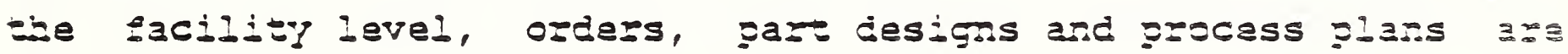

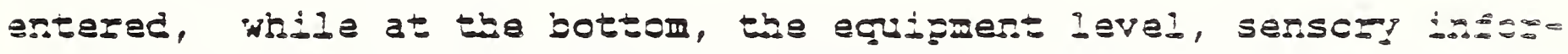
pation enters the system. Host oz this sersegl data is corsured

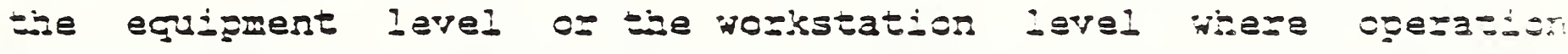

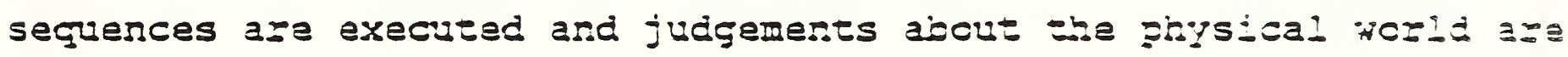

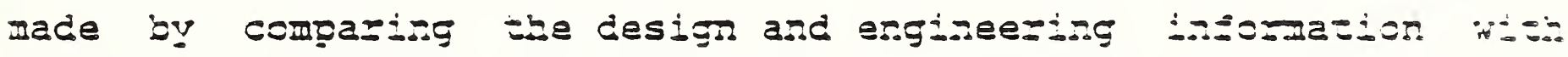
iccaliy acquized sensory insomation. Jotb the engineering däa

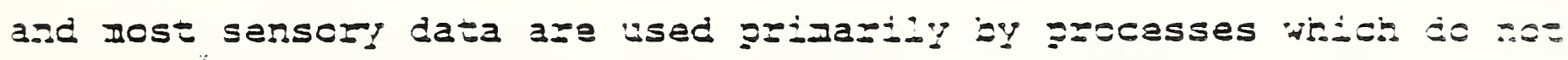

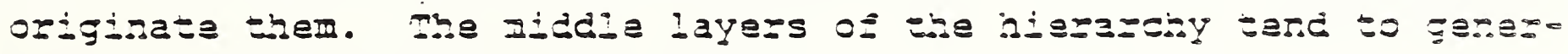

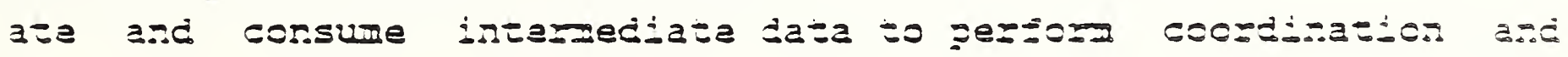


scheduling sunctions for the lower layers, and to srovide iso information useful in sacility plansing, eost acsounting and othax bigh level surctions.

While commands and status reports lollow the cortus? bierarchy, it is neither necessary nor desirable to recruire nose manufacturing data to do so. Forting a bierarchical data fas causes "proxy retrievals" by component systems with ro cinect use for the data and induces propagation delays without providing any furctionality. For example, a machioing cantaz at the egripmen: level may make a request for a NC Frogram which is maireained jy a design system at the facility level. If the data rere reguised to follow the bierarchical control chain, four transfers of the ve

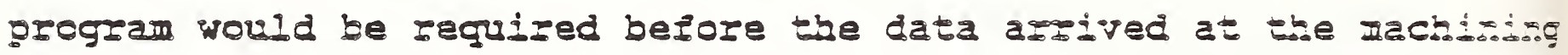
center. In the IMDAS, the data llow is not required to soliow tas control bierarchy. Instead, the control information idersiaiss the reeded data sets and the consuming procass dizactiy acsasses the actial data.

\section{4 .3 DISTRIJUTED DATABASE MANAGEMEUT TOEOLOGY}

The IMDAs consists of three service layers, each of which is resporsible for a defined set ef distributed data managemer. furctions. These surctions are distributed over the comperen systems accorting to their computational capabilities. The difangent layers of IMDAS scrtwarg work together in establishing, nanizulating and controliing the distributed dataiases. The laras grovides each componere system with ore or yore classes $c=$ diaj management serices. These classes are pefezred to as "basicl, 
"distributad", and "Mastar".

The basic data management services - command transiatiori data translation and commuication - are reguired to grovide access to the data residing on every component system. These services are provided by a Basic Data Admisistration System (3DAS) which is implemented and installed on every componert system.

The distributed database control and management functicis a query translation, distributed querg execution, and firal zasule assembly - are hardied by the Distributed Data Administzation system (DDAS). This software resides on component systams that. are powerful enough to support it. Not every system has a DEs. but everg system and thus everg contzol process has access $=0$ ena. The uDAs performs the functions of global directory maragement, data system initialization and data recorciliation. Ins "master" layer of data management sezices is requized wisen groups of component systems contuining more than ore DDAS are integrased into an operating segment of the factory data network. Jol eac: independently operating segment, there is exactly one Master Daza Admisistration system.

The indas architacture is somed by a byree-levei biezazoing

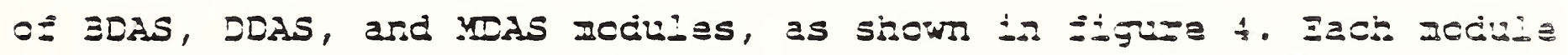
in the hierarcby controls acsess to cata within iss comain, lia is, within the entire sub-tree rsored by that zccule. Davajase maragement coerations are confined to the dcmain of a lodule is they can be persomed yy that module. Ctbernise, tiey aze gassed

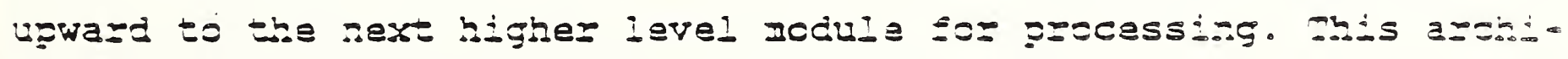

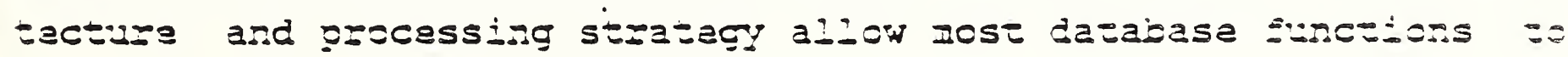


be carried out locally (i.e. within a module's domain) withoun causing unsecessary inter-processor comurication, syrchronizatili. and data transfers.

As illustrated in figure 5 , the intagrated database, which is physically distributed over the different component systems, together with the BDAS, DDAS, and MDAS zoculus Of the PADAS sezres as a central core through wilich al the CPI subsystums interact and comuricata.

Figure 6 illustrates the relationsisis amorg the IMDAs topology, the networl topology and the control topology, using the

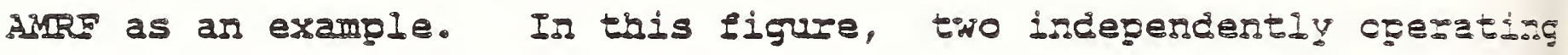
segmerts of the factory are sbown with the three tores of topological connections among the compcrent systems. 


\section{FUNCTIONAI DESCRIZTION OF MADAS MODUTES}

This section describes the modulaz czganization and sure tions of the three subsystems constituting the IMDAS: the sasie Data Administration System, the Distributed Data Administration System, and the Master Data Administratien System.

\section{I BASIC DATA ADMENSTRATION SYSTEM (BDAS)}

The zDAS provides a unizorm intertace betreen the casa residing on each component system and the integrated database. There is therefors a BDAS software podule zesident on everg cemponent system in the automated factory. Since the compcrent computer systems have widely different processing capabiliziss, the BDAS provides only. the essential data managemen: anc communication sunctions. These functions may be ingiemen:ea differenty in each component system to support the unigied haztware and software environment of the system. The functions of the BDAS are intezprocess communicazion, netrork sommunicatisn, data transiation, command transiation, and data zaragement. Tha azchitecture of the BDAS is shown in pigure 7.

4.1 .1 INTERPROCESS COMMONICATION

I: the component system houses multiple control and senso"?

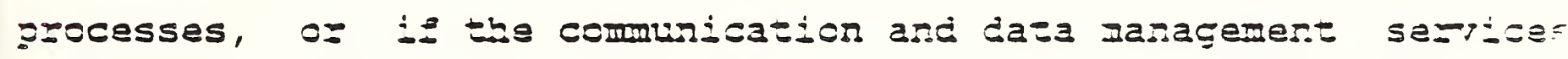

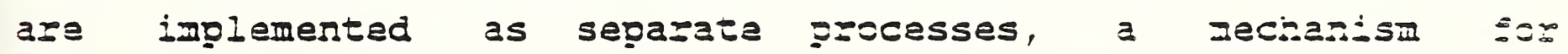
communication arong these processes is needed. Zntezprocess comunication can be achieved either by a dizact process-eoprocess zessage passing or jy using a shazed mezozy, depencing on the capabilities of the local epezaing system.

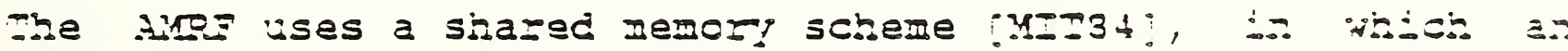


originating process stores information of a paticular kind or sor a particular recipient into a cesigrated area of the shazsd memory, and a retrieving process interested in a paticular insosmation set fetches it prom the preassigned area. mis sckeme has been implemented on different systems in the AMR in different methods - using a true bardware shared memory, using messace passing to a memory-manager process, and using a szscess ilines. copies the information between the local memory of each cancms? process and a backgrourd comon memor! [3AR82]. The shazad Iemory aporoach perits data to be used by more than ore process without explicit action by the origiator to deliver it to al: usezs. The shared memory can be considered as a cataicase is iss own sight, as well as a data commoncation vehicle sejuen isis control processes and the data serrices. The shared memer! approach is particularly effective is equipment level systoms which Iust gerzorll real-time data acgrisitien.

4.1 .2 NETHORZ COMMUICATION

avery component system mus have acsess to the factor? data retwork and must implement the protocols necessary to commincata Nith the other component systems. The IuDAS architectire szosumes

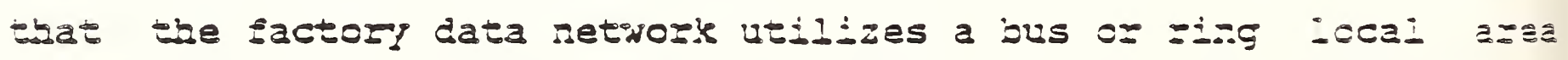
setworx topology, thereby providing a peer gelaticrsing jetreer. al component systems. The four lowest layess of tie Iso/OS: reference medel [IS081] must be imolemented for each comporen

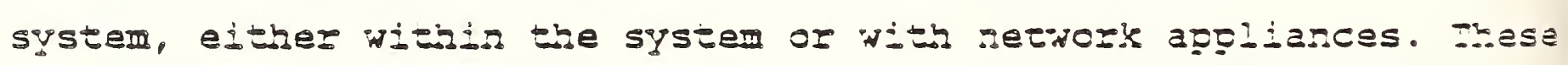
basic protocols allow zeliable commoicajion betieen any lic systems on the retrork. 


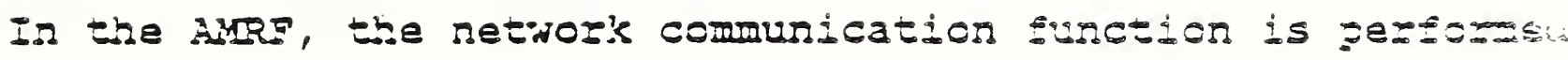

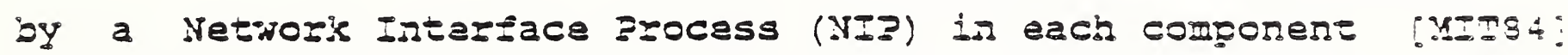

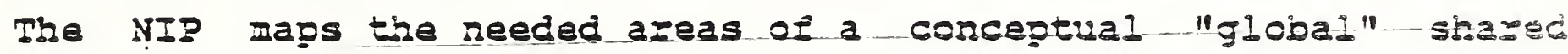
memory into the local shared memory. The mapoing is dore iy replicating the contents of its lccal shayed memorl into bis:

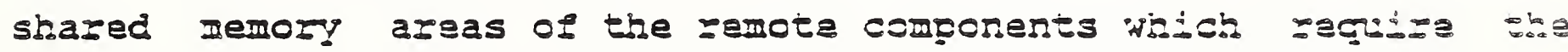

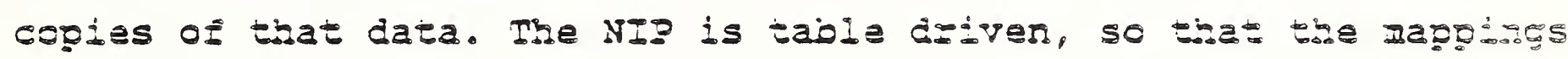

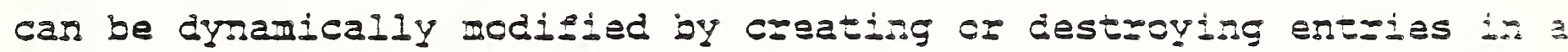
"delivery table". The acvantage of this global sbazed mexcm scheme is that it is a distributad database nechanisn wiblo ca. both contribute to and profit stom ctier database teciaigues used is the IMDAS.

4.1 .3 DATA TRZNSIATION

Thenever data are to be moved from cre systan to abotbes,

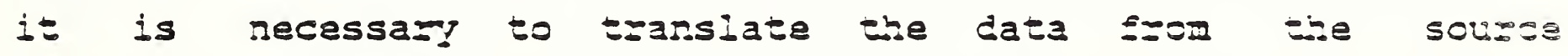

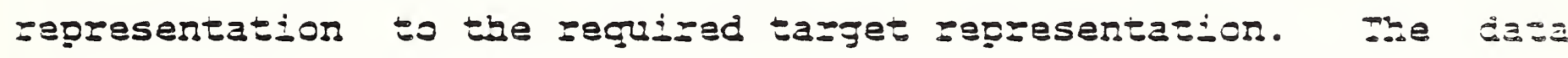

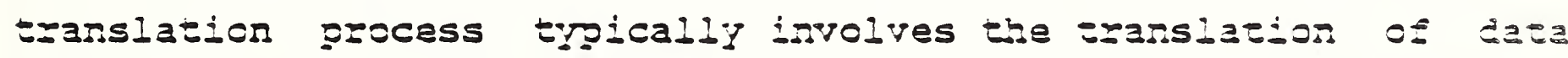

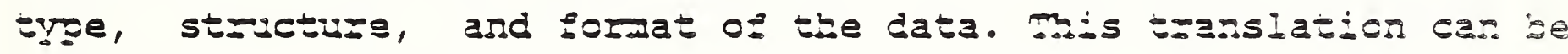
gerformed by eiliber dizect source-to-target conversion or scuraen

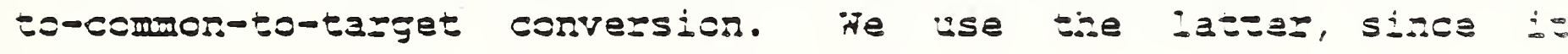

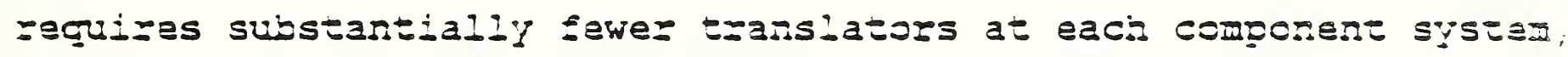
one local-to-common and one common-eo-local, as oxposed =0 (M-i)

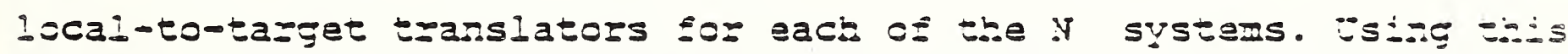

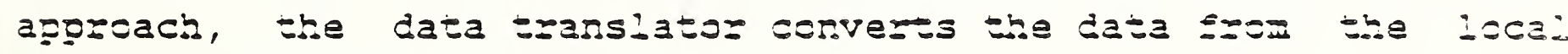

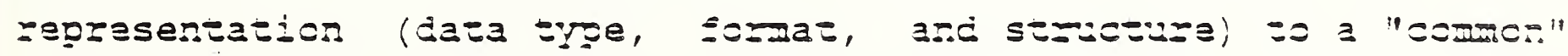

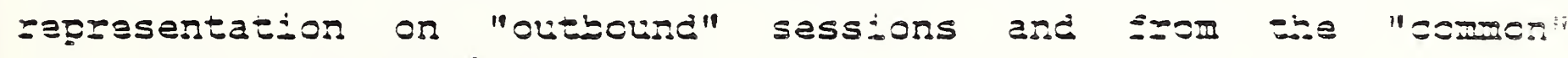
zepresentation to he local zepresentation or "i-jound" sessiom. 
gor each "session", the data translator must be given the syrtid of the messages for both the local and comon representation.

\subsubsection{COMMAND TRANSIATION}

In IMDAs, a global data manipulation language (GDMI) equegy issued by a component system is translated into a tree of stamkar grimitive operations by a DDAS. The function of command tyansia tion is to take each operation in standazd form and translate is into the query language or access mechanism understocd by the underlyisg physical data maragement tocl, whicb may be a diaza manager or file marager. Comand translation can often be tabla diven altbough some particularly intractable data structures zay req̧iz: prepregramed procecures.

\section{1 .5 DATA MANAGEMENT}

The 3DAS in each component system Inst grovide, through diga lecal database or file ranagement system, the actual acsess to sñ rasizulation of the lecal databases. The database manipulation and management capabilities can vary substantialiy from ore system is asotber, depending on the sacilities grovided by the softwaze. ix smali control systems, the lecal dataiose jay be implementec ani? id the main memory and managed dy a shared memery nanagenen process. In others, a sile manager may meet all local reçizaments, giving the system little more thar "gead" ard "ivitel" operations. In larger systems, scpristicated database managemer: systems ray grovide the actual database serpices. Morecver, theza may be more than one such facility on a sidgle comonent systen. The sequence of primitive operation comands given lo 
3DAS command translator must be rituid the capabilities of by urderlying data maragement systam which manages bise data. The da: manager must also be capable of ccoperating with the other dato managers is controlling and maintaining consistency, concurzang", and recovery. The minimal data manipulation capabilities of a BDAS are therefore "read file" and "write file", and tie minise? control capabilities aza "Iock sije", and "urieck sigell.

4.1 .6 BASIC SERVICE EXECOTIVE

The furction of this element is to provide a single point bs contact between the DDAS and the jDAS cata semices. The basid serpice executive accepts DDAs cemmands, souting them to the 3EA Iodules which perform the comand granslation, data manipulation, and data transiation functions. It also construcs iecal das delivery paths, secuerces the execution of query tree eperacions, and reports the completion or exror status back to the DLAS trangaction zanager.

The Basic Serpica Executive, because it somuricates with by DDAS and with its geer BSEs must bave a stancazd set of interfaces. Whe interfaces to the subcringate BDAS modules are :a some extert determined jy he local systam conversiors.

\subsection{DISTRIBTTED DATA ADMIYISTRATCR SYSTEM (DDAS)}

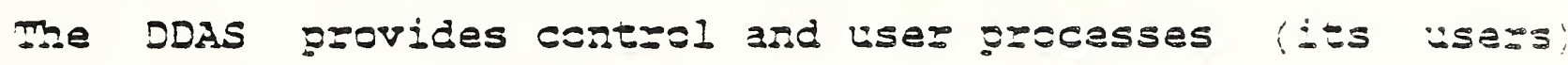

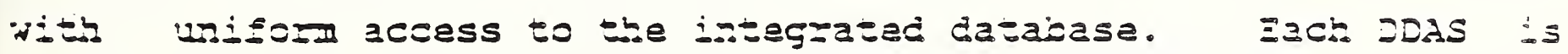

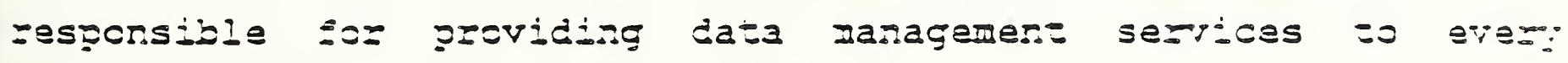

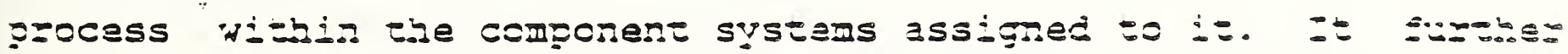

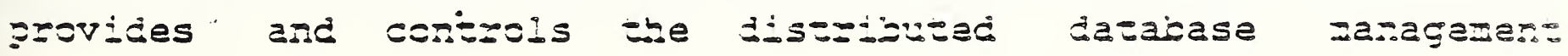




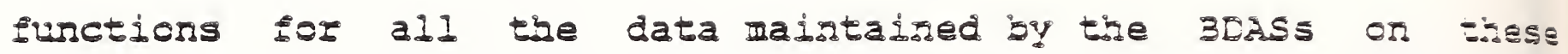
eomponent systams. In eaci separable group of comporent systay i.e. each goup capable of independent opezation, at least ox system must contain a DDAS. The major modules ol tae DDAS ass: tse distributed service execrtive, the data masigulation lasgrage service, the guery mapping service, the trassaction maragex, the

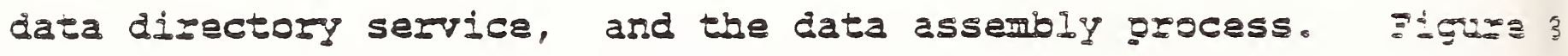
idustrates the intaralationship amcrg these modules.

\section{2 .1 DISTRIJUTED SERVICE EXECUTIVE}

This module oversees all DDAs activities amd provides bia single point of contact between the data systam and some set 0. users and betreen the IDAs and the MDAS. It is yasporsibis dox

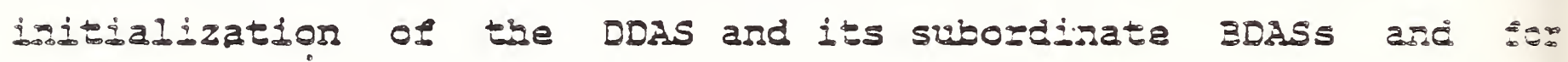
CSOİination of all DDAS Eurctions.

Therever a DDAS is brought up, it Ius= initialize iss dad

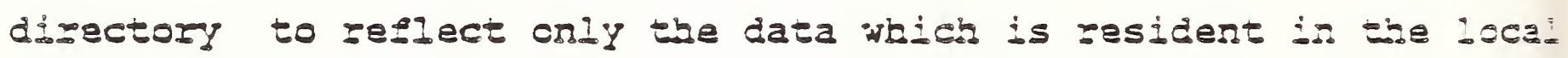
3DAS. It then creates comrections to its subordinate zercte jDiss,

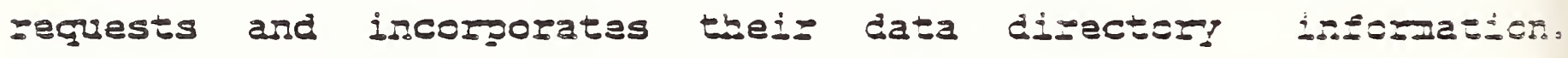
(Dizectory entzies of a subordinate jDAS data or file managez azo not accessible if the subcrdinate is dcwn and unst ise intacmasac

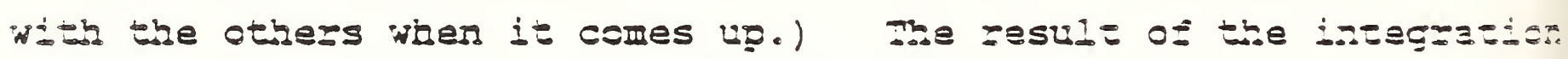

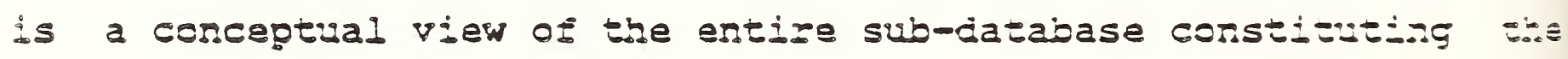

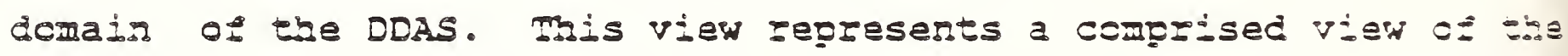

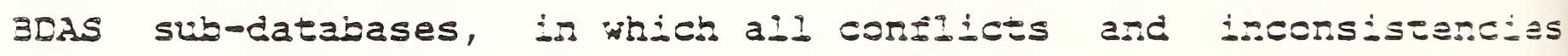
existing id the 3DAs dizectories are resolyed. The ISE vien iaina

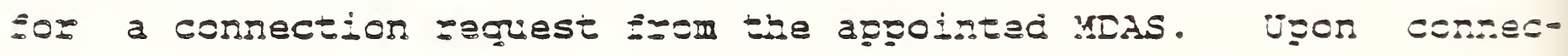


Elon, the MAS recuesta, and the DSz transmits, we zesoivad EDas directory for integration into the Master dizsctory, contanimg the definition of the global conceptual view and the mapping to the fragmented views of the participating DDASS. The DDAS would a: this time execute any MDAS-issued transactions for recovery er integrity gurposes to bring the global datajase to a corsigtarou

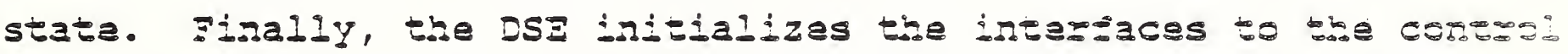
processes serred by the DDAS and is then ready to segin accerting zeguests for sezrice.

User processes puning on the DDAs comporent systems ismu data management transactions (often called "gueries", even tibugi they may be update requests) through the local or netrork inte:process commication services. Tpon receift of a transaction. Srom a user process, tive DSE rouves the transacticn to the jasa Manizulation languge Sersice, and hen detezines whethez wios transaction can be locaily executed. If it can, the ase passes the transacticn to tse querg Mapping sezise ard then on to bis Transaction Manager for execution. If the tuasaction cance le

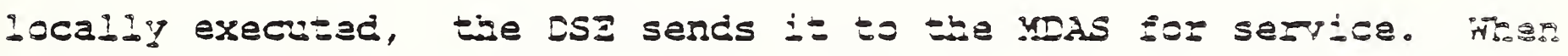
execusion of the transaction is complere, we DSE reports ios comierion status to ise originasing user.

The DSE must also sertice transactions originating trom etbas DDAS domains which are passed to this DDAS by Lie MDAS Transaceis:0 Marager. The ISE routes such transactions to the quez Majpine

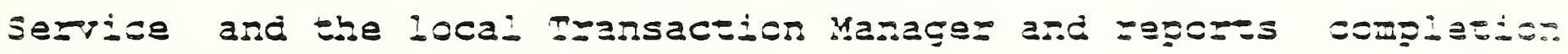
to the kis Transaction Manager. 
4.2.2 DATA MANIFULATION LNGUAGE (DMI) SERVICE

The DDAS receives transactions expressed in the GDM tron the user or control processes within its domaid. A GDKI grery is issued against the global extarmal view of the integratad catabas by the user process. To process the query, IMDAs car either

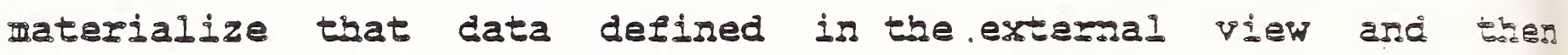
serord the query operations on the data, or modisy the givey toes so that the query operations will ocerata on the data defised in the global conceptual view. He chose tie grery locisication aporoach for its lexibility and efsiciency.

The DMI Server parses the GDMI Giery into a trae of grialtive operations on the extemal view (ar exterded set es paitional algebraic operations) and then ncdisies the guerl twa to iscopporate the rapoing from the extersal view to the glabl conceptual view. In addition, the DML serrer encodes inso tha grefy tree data deivery operations, which zeference the usexo desigrated source or destination data aras. The giesy tyes jay be then furber modified to incoporate securitug constrains de-

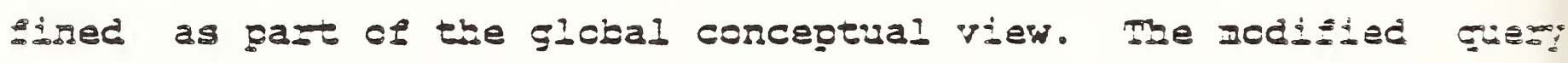
tree now constitutes a transaction on the global conceptual vien,

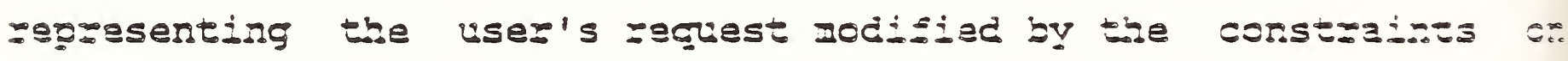
that user.

The DML Serrer inen identifies whether the requested operations can be performed entiraly by this IDAS, jy examining tia

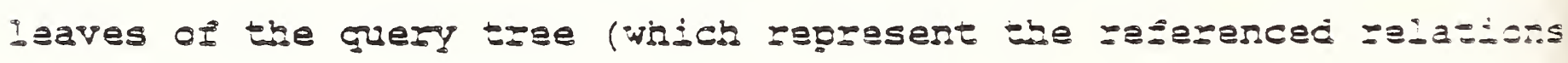
and ats=ibutas) and consulting its dizectorg to see if lie daca zeferenced by the quezy reside is its component systems. If any of 


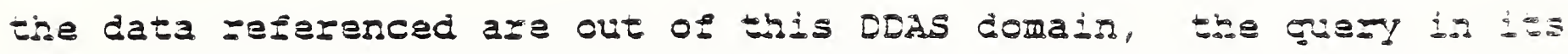
transiated form is flaggad for tzarsmissicr to the MDAS maz further processirg. Otherwise, the guery is flagged for processing by the local Query Mapping service.

During the above operations, the ond server makes lse 0 . viow and constraint mapoing inforation and data localisy insomse lios provided by the local data disectorg Serides.

4.3 .3 QUERY MAPDIYG SERVICE (QMS)

This sefrice accepts from the DSI giefl twees, as translated by the IMI server, which car be satisfied eris-aiy withid the sub-databases of this DDAS. These gueries may Dayk come from local users or from remota users via the MDAs. Ihe Cuan: Mapping service decomposes each quefl irto ore or zora faeries la

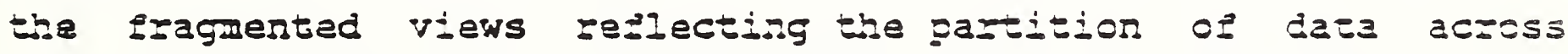
sibordinate BLAs databases ard the capajilities of the data sez-

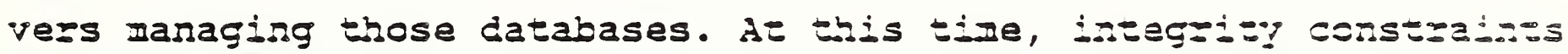
defired id the rapping from the glosal corceptual oijew to the

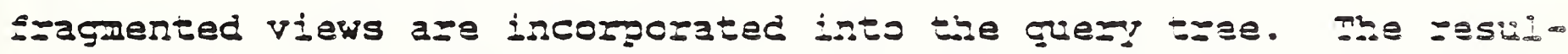

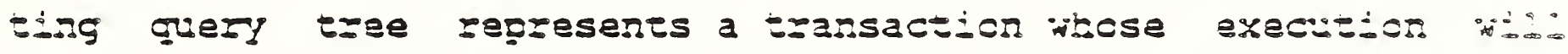
guaratee that the distzibutad dasabase

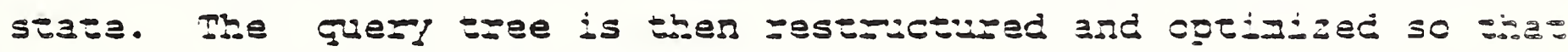

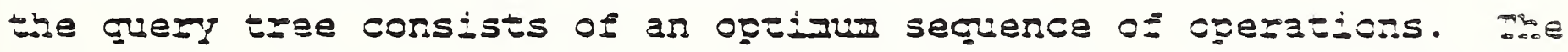

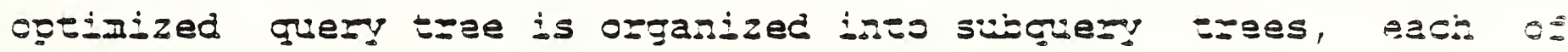

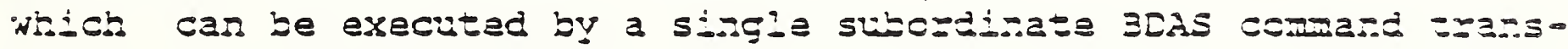

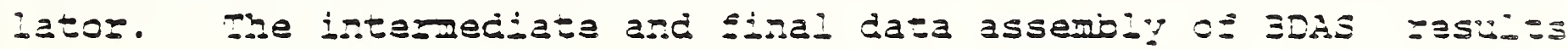

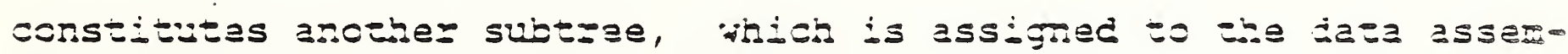

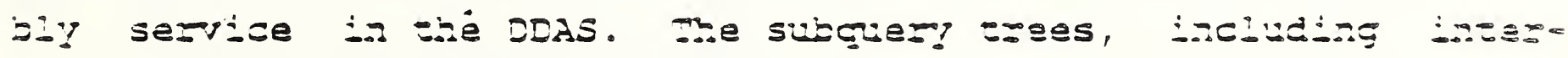


nediate and final delivery operations, and precedence zlation. ships, are now passed to the transaction manager for exacusicn. During the cruery modification and optimization steps above, the OMS uses data locality information, profile information (the amount of data at each ncde) and BDAs comand translator capability information provided by the local Data Diractory serpics.

\subsubsection{TRANSACTION MANAGER (TMI)}

The transaction manager performs the control anc nanacement of distributed query execution, including enforcement of darajase integrity, concurrency control and recovery. The integrity contwi mechanisin of the TM realizes a serial execution schedule for each transaction recrived from the query Mapping server, whie insuring that ibe transaction is processed as an atomic unit of recovery. The recovery facility of the $\mathrm{mr}$ briags the database back to a consistant state after a system failure or a violatien ef abo integrity constraints has been detected. The TM performs is transaction and database recovery by selectively delecasing recovery actions to the 3DASs, by properly maintaining distributeq checrpoints, and by difectirs parailel activities of the SDAss using the two-phase commit protccol, as recessary. The corcuryano oy control mechanism detects conflics berieen active and percinal transactions by identisication of comon attiilute references. Pending transactions which weuld conjict with active hransactions

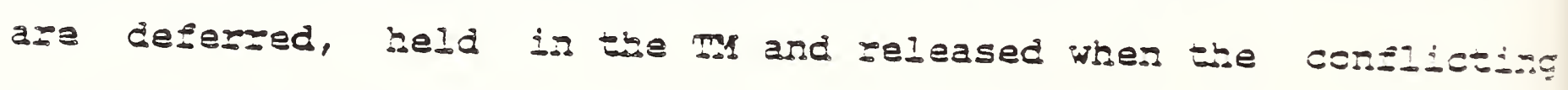
zzansaciien completes.

When a transaction is released, he m tuansmits the propez sub-ezees of the query tyee, along with the dizections for con- 


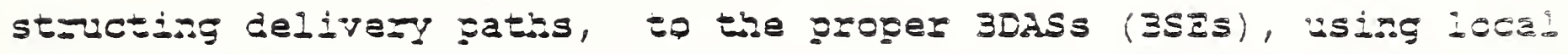
or detwork communication servicas, deperding on wisez tae 35js resides. Ma MY oversees the distzibuted execution of liese opezo ations, receiving status reports exoll all of the 3DAss involved. When. the final zesults ol the tzarsaction have been deligezed to

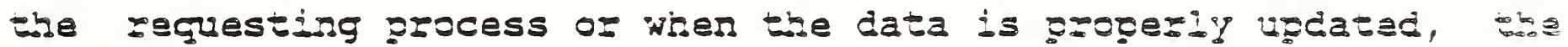
Th identifies the tzansactior as completad.

meansaction management in InDAs must supgot not chiq ezansactions chazacteristil c: corventioral database envinonmer.s

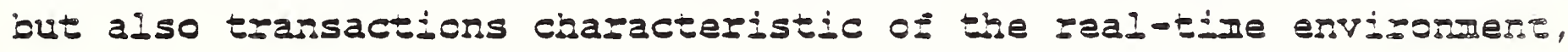

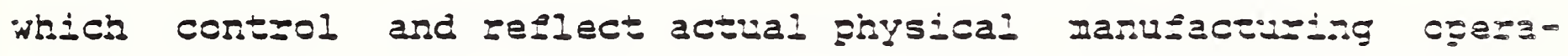
tions. Such transactions zeflect the stata and location e: objects in the factorl and affect. the gezceptions and decisions of otber control processes. mey ixclude simultanecus ipdates Exas zactile and visual sersors when a jat is grasped or sinulzanecus

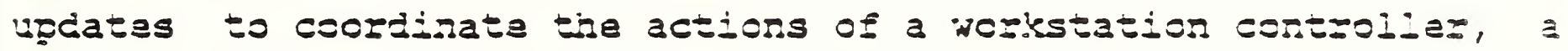

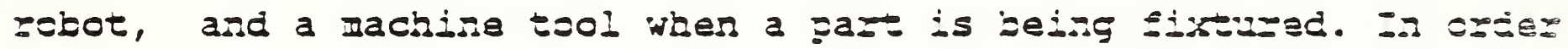

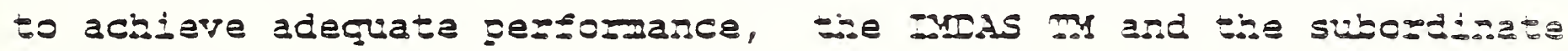

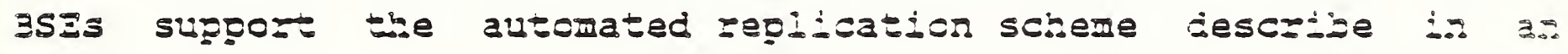

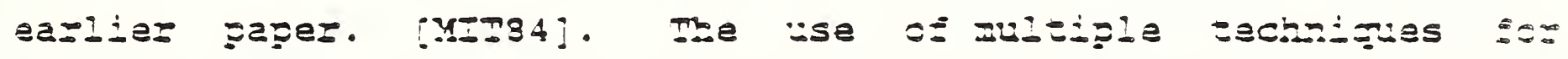

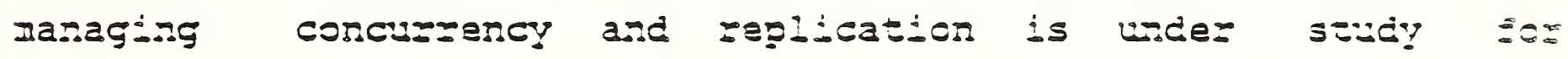
maintaining data integrity and its comesponderce to giysisaj =aIi-s.

A.2.5 DATA DEESCTCRY SERTICE (DES)

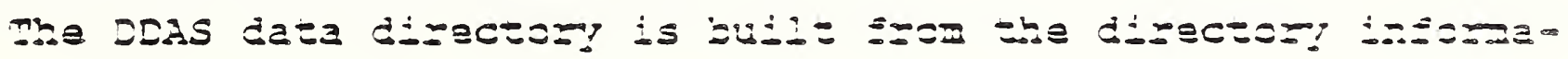

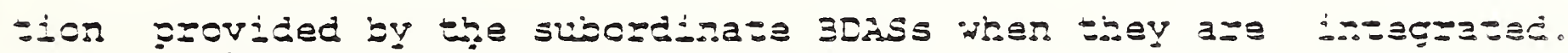
It iscludes be soliowing zesadaza: 
- the schema and mapoing information for the global csrckn tual and fragmented views of data rasididog on subczinata 3DASs,

- the mapping information for the external and conceptual views of the data referenced by the control frocesses which this DDAS supports,

- the security constraints associated with the viaxs of the conceptual database referanced by the local contool processes,

- the integrity constraijts associated with the data ia subcrdinate BDASs,

- the profile isformation on the collections of data at wos 3DASs,

- the data delivery information zacuized by the netroxk ard iztaprocess comurication furctions to construct delivery gatbs,

- He inomation representirg the capability of each sus ordinate Dems or Command Translator.

Wher recuested by the LMI sezrer or the oMs ox the Th, wa Data Directory Serrer perlorms a metadata lookno ard provides data location, structure, asd delivery insomation.

\section{2 .6 DATA ASSEMBIY SERYTCE (DAS)}

This mocule performs selection, join, union, intarsectien, merging, sorting, and other final amalgamations of dava zes=ievec sxom subordisate 3LASs, and mulipile projections of user-proviciac data for distribution to subcrdinate 3DASs for updates. Is:s

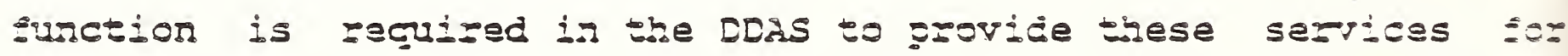
sDASs wible have only limited data management capainizies. It is also reeded when data are zatrieved from uluiple scurces. Inis

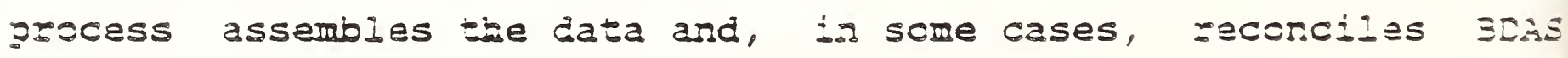




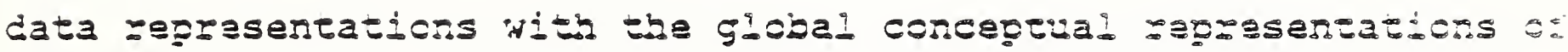
those data.

\subsection{MASTER DATA ADMINISTRATION SYSTEM (MDAS)}

The furction ol the MDAs is to coordinate the activitios 0 multiple DDASS. This coojination consists primanily of lanagiab

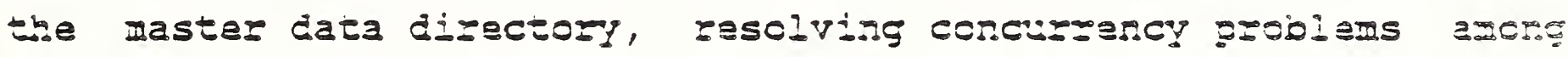

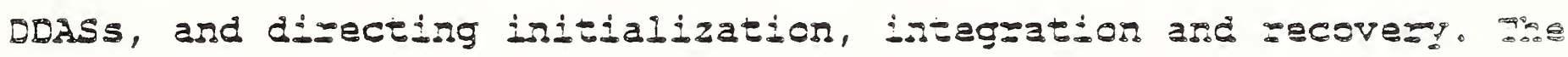
softhaze reeded to accomplish this functicn is zasident in eyer:

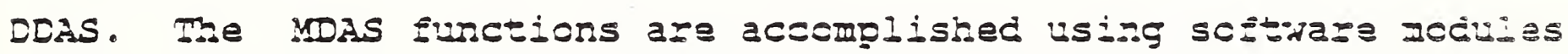
largely identical to the DDAS mcdules; differences are concero

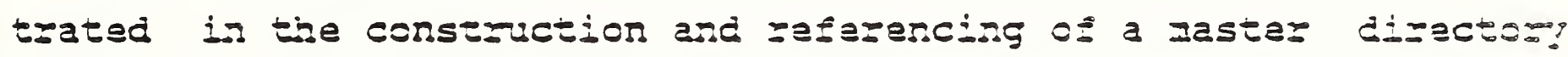
containing the data definition of the global conceptial view and the Ifagmentation mappings to the individual DDASs. Tyezefore, sio

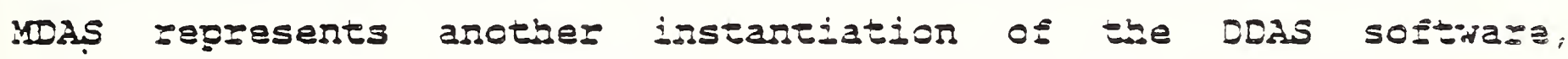

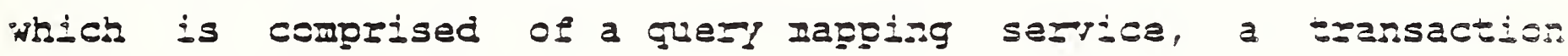
rarager, a data directory sertise, and a daza assemily process;

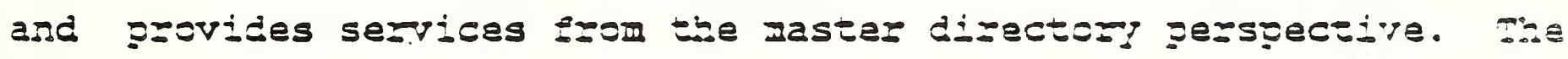

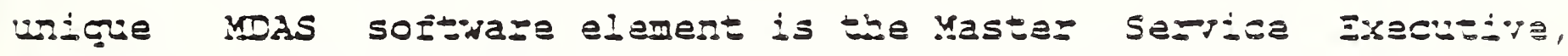

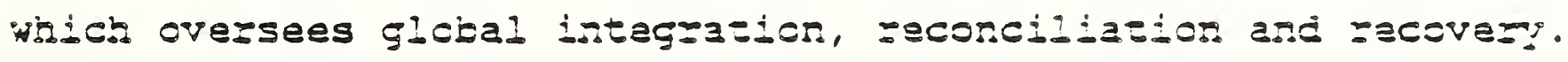

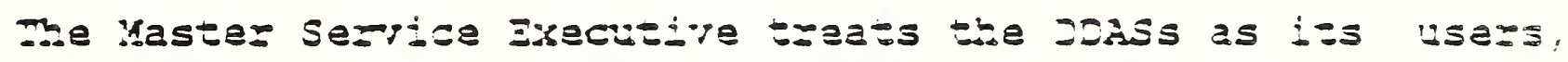

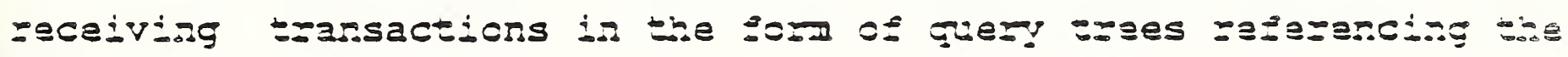

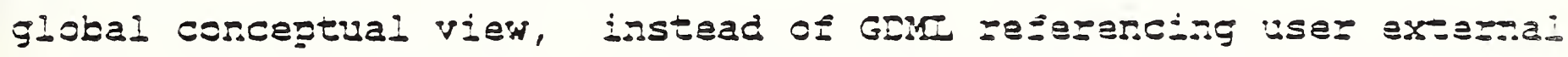

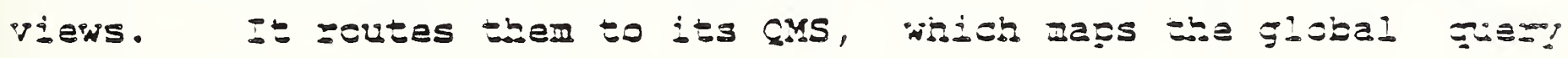

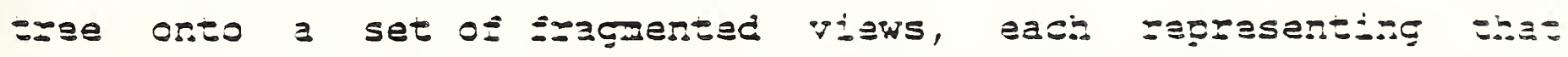

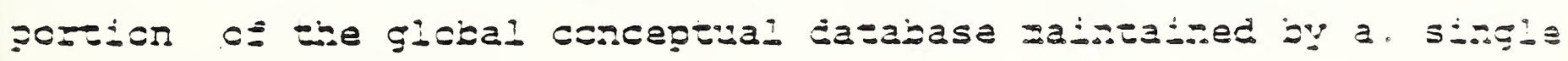

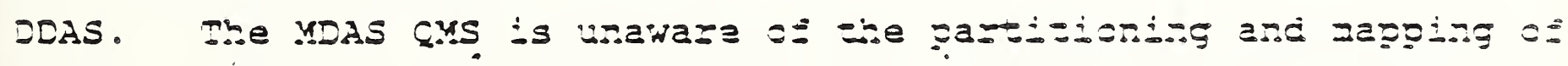

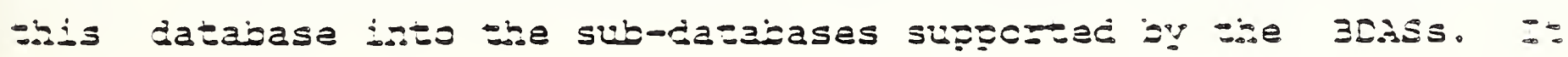


sees the DDASs as a set of ufiforx subcrdiratss, each ol which has the fisl spectrum of data management capabilities, and each ot widich ranages a fxagment of the global conceptral datajase. The ingmented view queries delivered by the oMs are then sent to the Master Transaction Manager, which distributes the fraguents to the

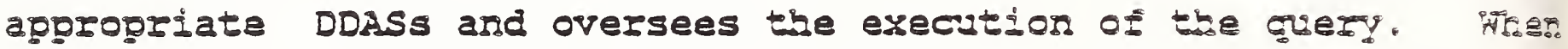
the transaction is completed, the MAS TM reports ihe completion to the MSE. The MSE sends the report to the originating DDRs, idse is responsible for the commuication with the originatiog lisa. As is the case of all DDAs ocezated grefies, the date deligem operations are contaised is the querg trae and the firal ditu delivery is direct izom the system which exacutes the scot ojexa tion id the quefy tres to the desigratad azsa or the user's syster.

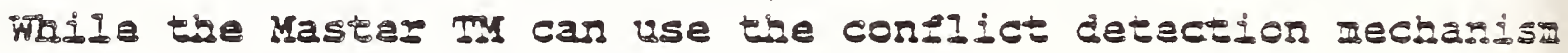
employed by the DDAs TMs, this mecharism, inich successfuliy avoids corcurzercy groblems at the BDAs level, canot gramasise the avoidance of concurzercy problems at the cLAs level, jecause the DDAS maY be executing tzarsactions of local crigin, abcus Which the MDAS has no information. For this reascr, the MISAS TM must employ a cooperative concursency cortsol justcol on evey tuasaction which is sagrented to jore tian cre DDAS.

Ia the istegrated factor!, there Iust be exactiy ore nifs. When the data system is isitialized, an operator designates one DDAS as the MDAS and directs it to intagrate tie ctief IDASS.

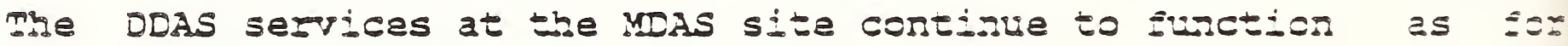
any other"DDAS. If an MDAS goes down, an cperazor. desigrazes oro

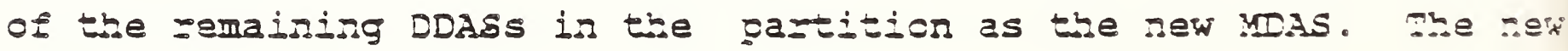


MDAS must zobuild tia master dinactory and initiata a zocovemy procedure. When the data system is patitioned to aliow a nuzise of sub-netions to zur independerty, an MDAS is established fe: each partition containing more than one DDAS. Each vals regrests its subordinate DDASs to provice thair directories and irtegrates

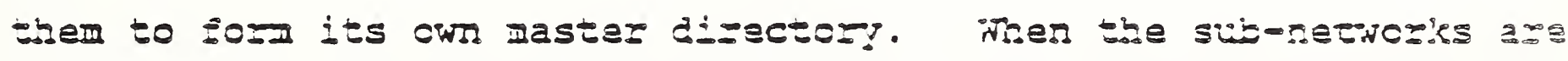
subseguerty reintegrated into a siagie data system, tie Mas usas the recorded inzormation to recorcila the sub-datajases. 


\section{SCENARIO}

To illustrate the operations of the IMDAS pocules and thet: functions, we will present a discussion of two scenarices which use the AMR testbed to describe the interaction between zodules. scenario I illustrates the servicing of a query from one compcrent system which accesses the data stored at arother compionert systu. In this scenario, the query is issued by a workstation eontrot system for retrieving the work-in-process data from a roves cortrol system (RCS). Scenazio 2 describes the precsssing of GDMU query issued from an operator interface for the workstation status data which exists at yore than one workstation in the Mus.

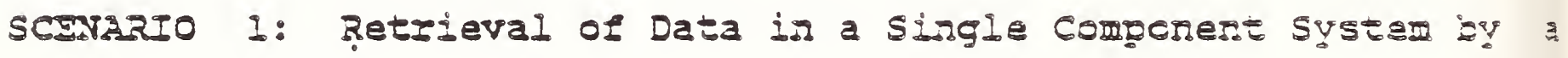
Remote System

In this case, a workstation control system zaciests the sar: tyoes and courts of all the workpieces in a busfer ayea maintuined by a local robot control system (RCS). The workstation will laka its request using the GDM. The following is a description of the different sets of operations in the scanazio which zepresant the actions taken by the IMDAS to process this grerg:

Set 1: 1) The worlestation control program writas the grew? to its data service command area. 2) The zDAS communicasion system at the workstation forwards the new guery to its controlling DDAS by netwcrk or local inzerprocess comunicanion, ceperiing on the location of the DDAS.

Set 2: 2) The DDAS Distrijuted Service Execulive receives 


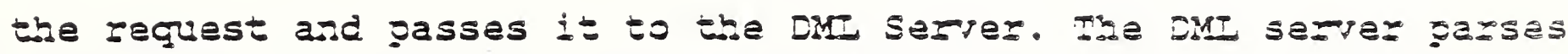

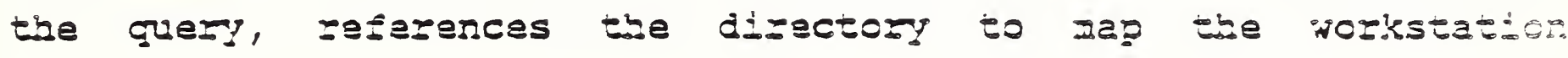
controller view into the glcbal corceptral view, locks up job referenced entities, builds a grey tree on tbe GC piar, determines that the guery cas be done by this DDAs and repots bo

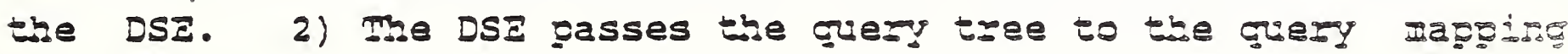

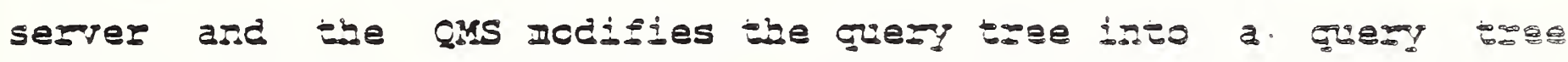
consisting of cperations that the 3LAS on the cosot contsolder cas

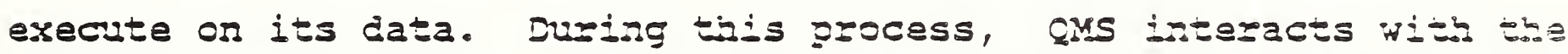

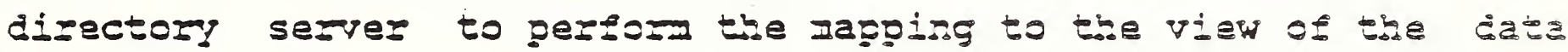
held by the kobot controllez 3DAs and then repozts to the DSa. i)

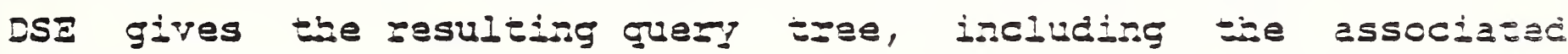
delivery information, to the transaction manager. ma transaction rarager checks whether there is ary urdate of the workisice daje

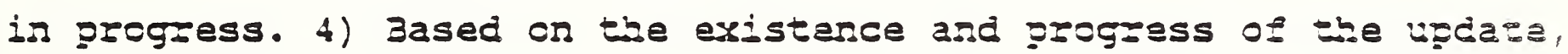

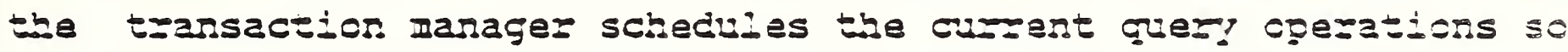

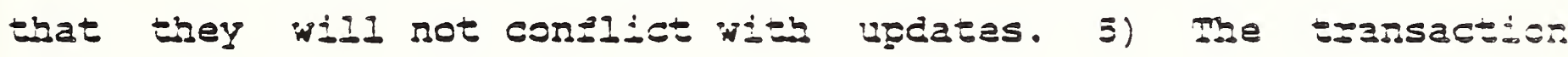
marager then delivers the quezl çezaticns, tieiz sciecule, and

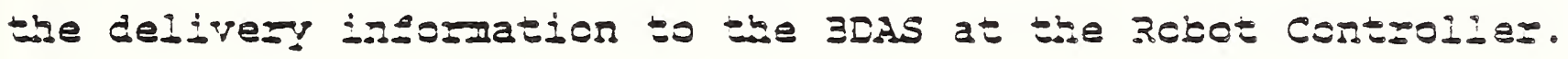

Set 3: 1) me basic serpice executire is the 3IAs at -is

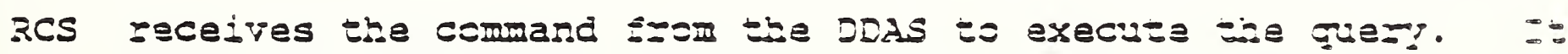
corstructs tie data deliver! path back to the icristation contos:

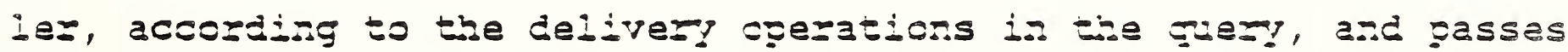

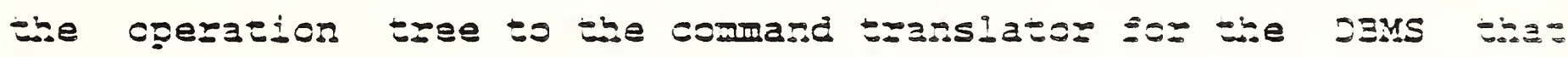

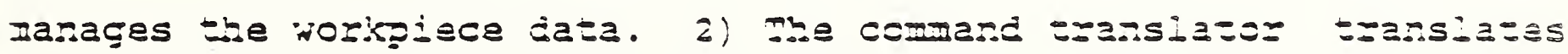

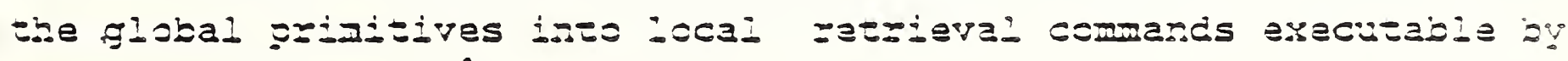

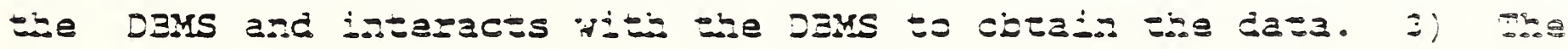


data translator converts the data into the IIDAS standard repro sentation and delivers it to the Netroys Interface Process. 4) The NIP copies the data in standard form to the peer NIZ at the worlestation and reports the delivery to be BSE. 5) The 3asie Service Executive raports the completion status to the DDAS twarsaction manager.

Set 4: 1) The worlestation network interface process delivers tia workiece data through the inter-crscess communication service to the requesting control process. 2) The TM at the. DDAS raporis completion of the transaction to the Distributed serpice Imacitive, which provides the firal status zeport to bie requestiag workstation control process.

SCEMARIO 2: Retrieral of the Data Distributed at MuItidele comporent systems

In this scenario, a GDM guery is issued by as sperater interfaca to all the worlestations requesting the weristatic: identisication, the identification of the current job is procss ard the expected time to complete the curent task. The data

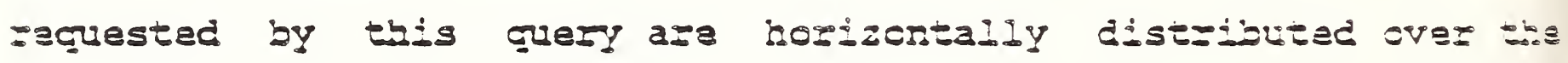
different workstation status zeports twoughout the factor?. Fibe sollowing sets of operations occur in the ImDas to retrieve ine data:

Set 1: 1) The cperator intertace srogral witis the retrievai transaction into its data sergice comard area. 2) The BDAS at the operator station recegrizes that a new regues exists 
and delivers it to ha LDAs, id his case a local sycess, inะer-process commication.

Set 2: 1) The DDAS ISE receipes the reciest and passes is to the DMI Server. 2) The DMI server parses the zagust asc obtains the mapping and lccation information fyom the Digectopg service. The disectory indicatas that scme of the raferanced dasu

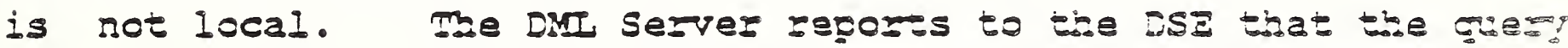

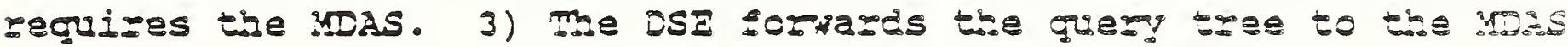
via tise retrork.

Set 3: 1) The MDAS Master Sezpice Ërecitive zacripes bof query tree. It then cbtains the description and location insora. tion from its difectorl sezrer, Hbich indicata ibat tia dasa

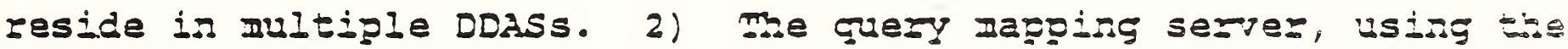

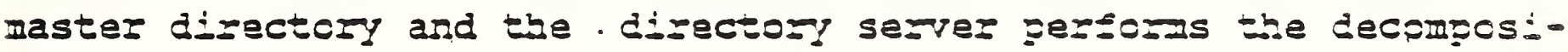
tion of the query into a guery tree of griaitive cyezations is

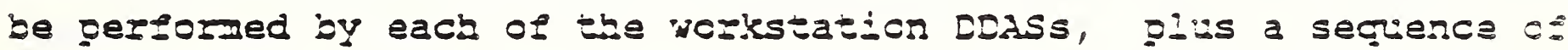

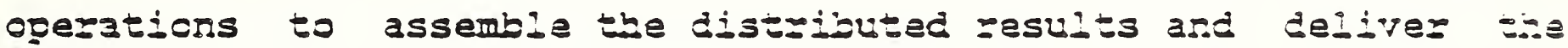

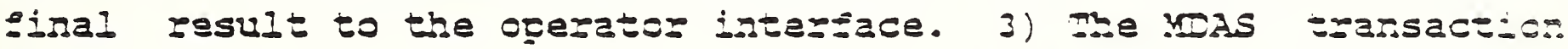

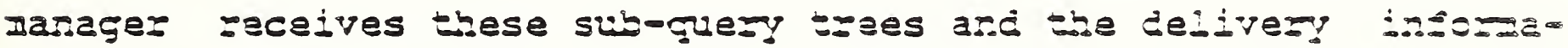

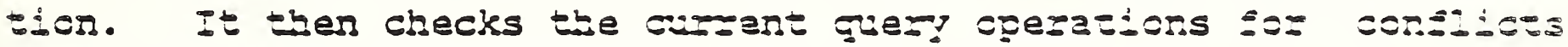

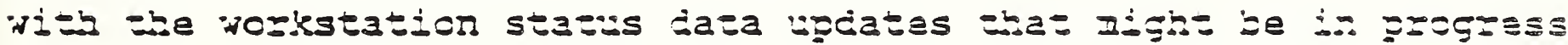

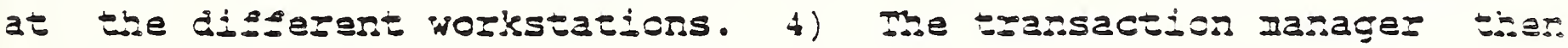

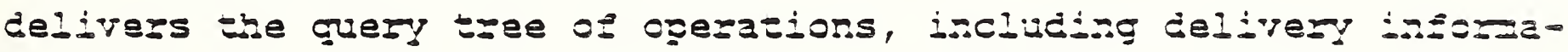

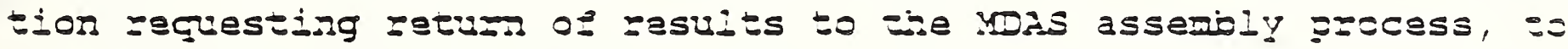

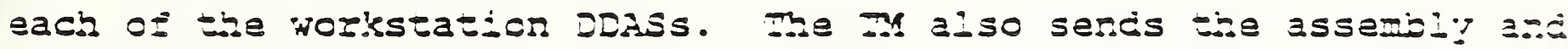

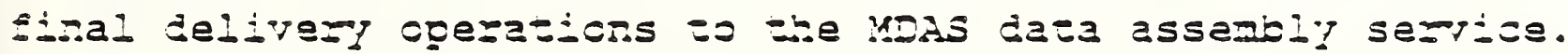

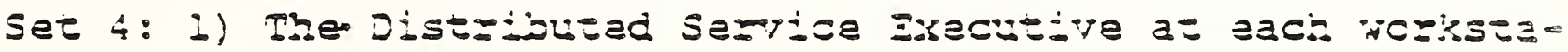




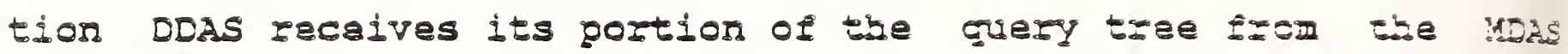
ard passes it to the locai Query Mapoing serica. 2) The cks assigrs the primitive operations to the underlying BDAss acsoming to the physical locations of the data to be procassed by the orimitive operations. 3) The transaction managers at these IDASS then schedule these prinitives lor execution and send these gadio bive operation comands and the delivery information (Foldist bs the MDAs assembly azea) to the propez underlyiag IDAS.

set 5: 1) The 3DASs at tie workstations with the data crats ba delivery patb to the Mas assembly azea, setrieve and corvers the data using command translation and data translation as in the the ilist scenario. 2) The network comunications services of wis 3DAss deliver the fotrieved data in standazd sorm to the setwexi comurication serpice at the MDAs station, which delivez's is bs the data assembly service of the MDAs. 3) The assigned cperation comoletion status is reported by the basil sefrice execulives. is the 3DASs to theiz DDAS transaction managezs. 4) Jach LDAS t=3.5action manager, upon completion ol its subtree, zeports bes completion, via the DSE, to the MIDAS Mansaction Managez.

Set 6: 1) The data assembly sezice of the wDAs zeceites ibo

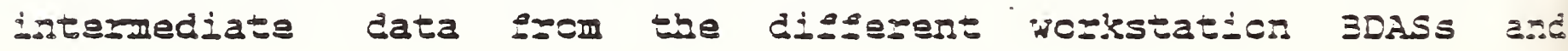
serforms the data assembly surction. 2) The assemiled data i.: sidal lor is delivered, via retrork serilces at tie uIs and coerator inteztace stations, from the NIAS assembly service to tia area designated by the originating clezator interface grccess. i।

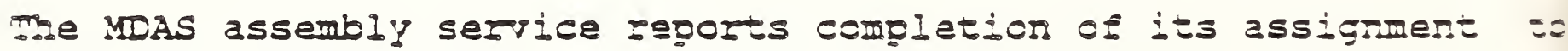


the MDAS MM, and the TM peports compietion of the rhole tasaso

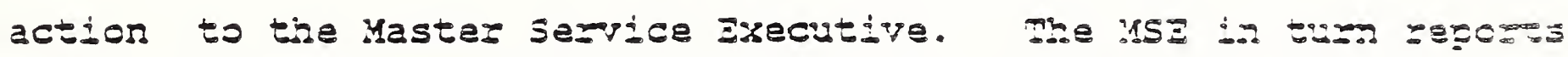
completion to the DDAS reom which it received tie zegrest, sameiy the DDAS servicing the operator inteztace, and the DS a wers reports final completion of the transaction to the operator inter sace process. 
6. SUMMARE, STATUS AND FUTURE DIZECTIONS

The development of dist=ibuted database managenen: tecbriones is of fundamental importance in realizing a totally integrated and automated sactory of the figure. Mis characteristics of the CIM environment introduce database maragement requirements which are quite different from those of other apolications. In this paper, we have identified thesa requirements, and based on them we have cesigred an Integratad Manufacturing Data Bcministration System (JMAS).

The INAS architrcture acdresses a hetergeneous distrisutá database environment for managing manufacturing lesign, glansisf, and control databases. It consists of a three-level bierazchy ot lata management subsystems, the Basic, Distributed, and Maste: Data ACmisistration Sertice modules (3DAS, DDAS, and MDAS), Nbici aja distibuted over the comporent systems of the automatal factory. A BDAS exist3 on every comporent system whili can grovide the basic data maragement ard commoication capaisi= ities recessary to process data residirg on that system. The IDAs mcdules resolve disferences between their component systems and the "IMDAS standard for". Jverl BDAS is supergised by exactly one DDAS. A DDAS, througi its subordinate BDASS, yanages ail elements of the integratad catabase residirg wi-bia iss cemain, and provides ali data manipulation and cata directs:? services on these elements. The DDAS also provides tie control

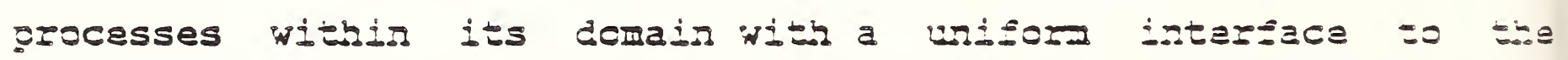
integrated database. Typically a SEAS resides on 72 jo componer: systems in the factor!. The rDAs handies the schecuinge and 


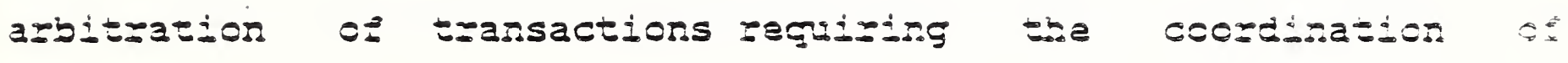

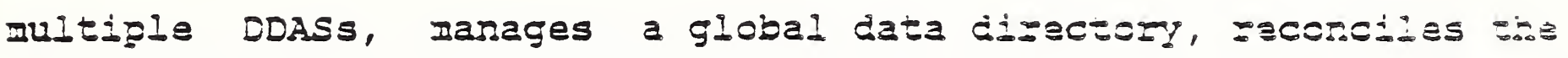
DDAS dizectories, and controls the zacovery of the data distaio buted across all the DDAs comains. In every ocerating zatidion

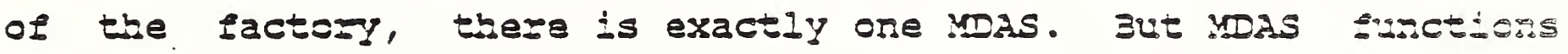

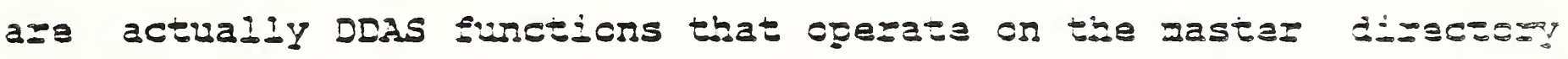

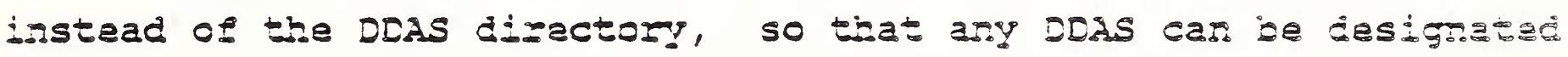
as the MDAS.

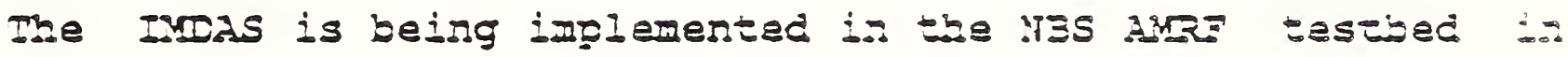
order to demonstrate the feasibility of this desig.o ard se grovide a hererogerecus distributed database grstotige fos

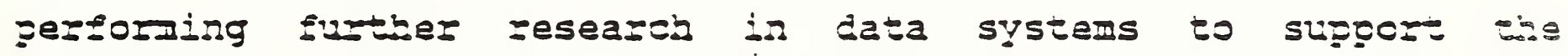

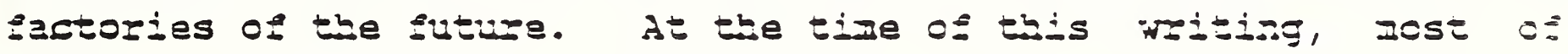
the SDAS furctions bave been inglemented and lasted on sepera!

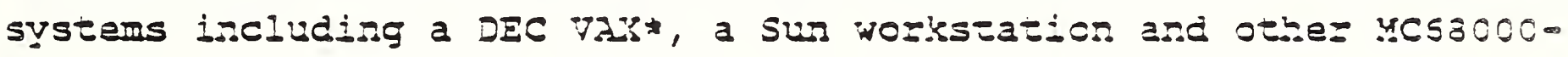
based systems, axd Ixtel Multibus-iased systems. Csasidezabie

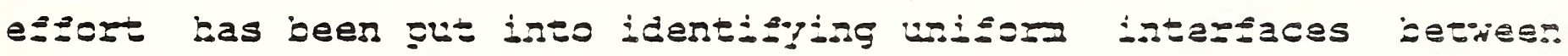

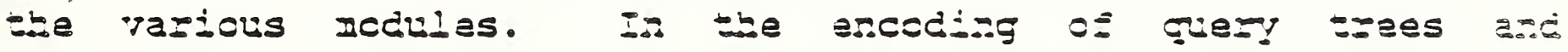

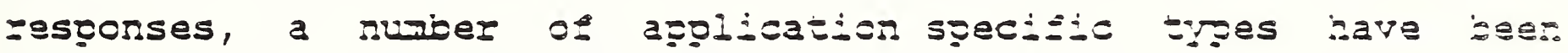

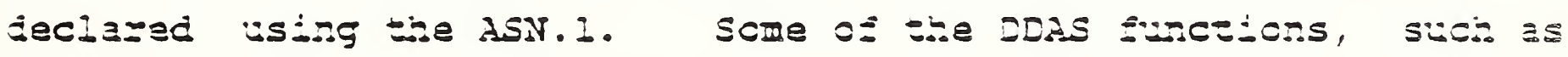

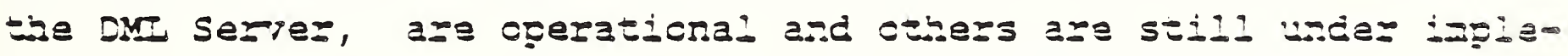

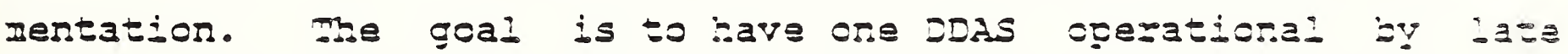

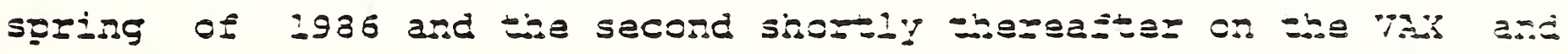

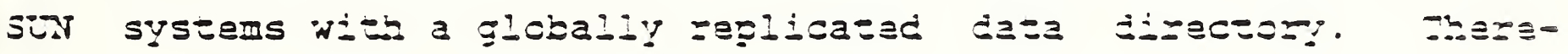

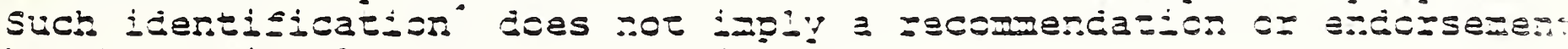
jy lie Yatisral उuะazu o: Starcajás. 
after, a third DDAS software set will be implemented on an :as 4300 series system and the eirst MDAS prototipe wiIl ze attamptok. There are a sumber of areas requiring further researdi is the IMDAs framework. Proper techriques for iritialization, recovery and reconfiguration of the factory data system ars critical to the successful support of future CIM envizorseres. There needs to be a detailed investigation of these tachnigues is the cortaxt of their effect on factory databases.

Factory data operations often create or rellect changes the poysical world. The physical charges, hewever, hiv dramatically different tire-scale żoll theis isgica: courterpars. This presents special problems in integrizi and coincrusency control in the sactory databases. coordination and synchronization of distributed transaction maragemer. fructions, and the proper cocperation betiseen the was admisistration system and the control systams are key yesearci. azeas.

The database query grimivives that can be executad by capable systems are lairly clear (e.g. relational algebra cperations). "owever, the primitives to supcort systams with limitad capabi:ties and the interaction Nity ncre capale systems need to ga investigated suther.

Classifying data into different lisses and designirg prope: techriques for these different classes can simplify the various database control tachrigues and can provide betre data nanagenen: gerformance. An intalifgent classification of the daca ay 


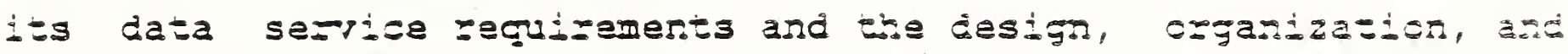

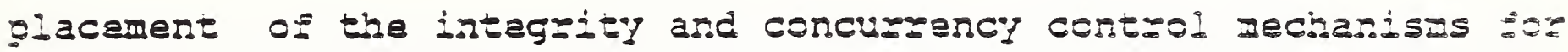

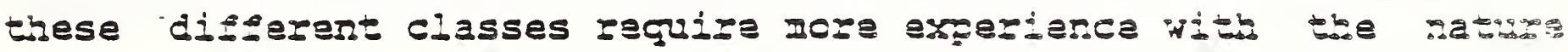
and use of the CID/Car data.

Al of these areas, add probably ethers yet to be

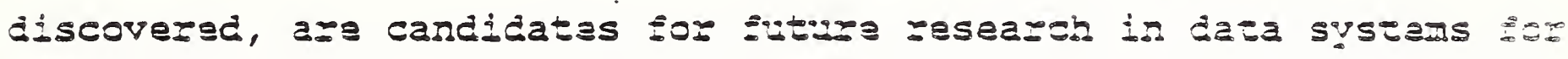

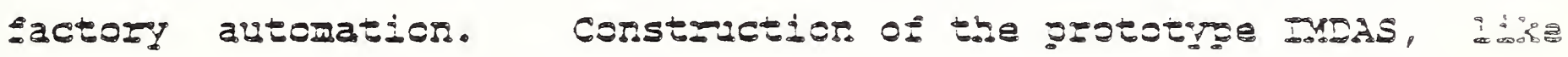

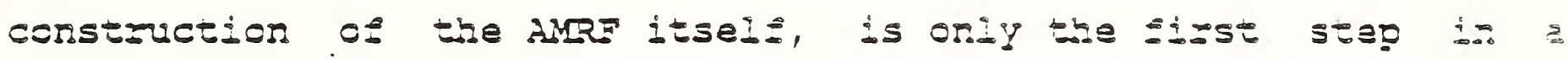
srogram of zesearch supporting the factorg cf the futura. 
[II381j Albus, J. S., Barbera, A. J., NageI, R. N., "mbeen!

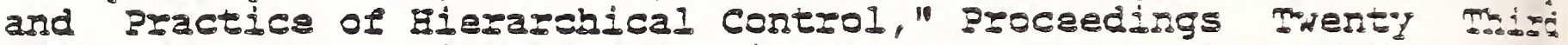
IEgE Computer Scciety International Conference, septemeier 1381: $18-39$.

[ANS85] "Dratt Proposed American National Standard Database Language SQI," American National Standards Institute, InG., MNS 3SR 3. $3.15-198 x$, Februafy 1985.

[3AR82] Barbera, A. J., Ėtzgerald, H. L., Alsus, ש. S.:

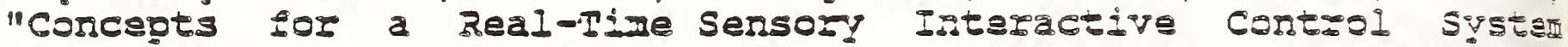

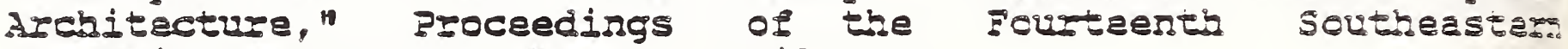
Symposium on Systems Theory, April 1982.

[BER80] Eermestein, P. A., et. al., "Intxchuctich to a systan fos Distrisuted Databases (SDD-1)," ACY TODS, VOL. 5, NO. I, HaY I980.

[3RA82] BraY, 0.Z., "Distzibuted Database Maragement Systams," Lexisgtor Books, 1982 .

[CER84] Ceri, S., and Pelagatti, G., "Distsiouted Dataiases: Drixciples and Systems," MC GIaw EiII Co., 1984.

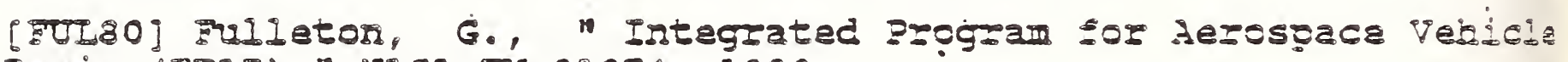
Desigh(IPAD)," NASA TM-81374, 1980.

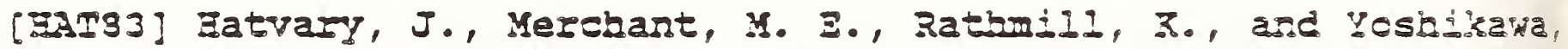
3., Norld Survey of Chi, Buttarnortb \& Co. Lid., Kent, UK, I983.

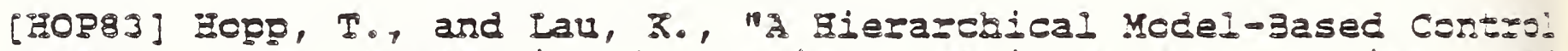
Systam for inspection," Americar sccietil sor Testing an Matazils, May 1983.

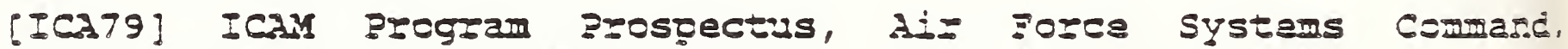

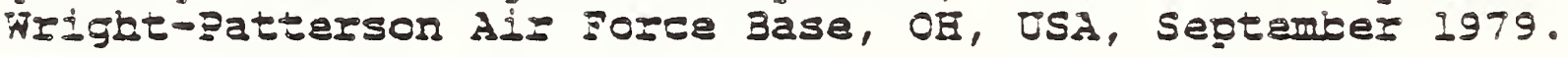

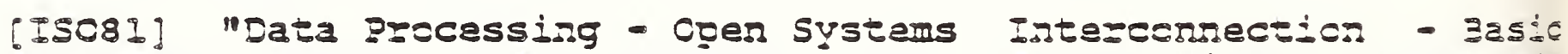
kederence Model," ISO standa=d 7498, Intanaticnal Standasis ozfanization, Geneva, 1981.

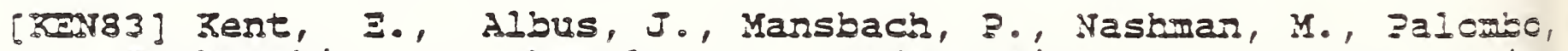
L., Kutkowski, W., Wheatley, T., asd Skreier, M., "Robot Senside

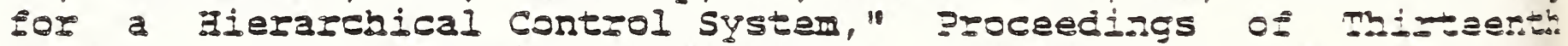
International symosium on Industuial Rotots/Robots 7, Chieago, Ii, April 1983.

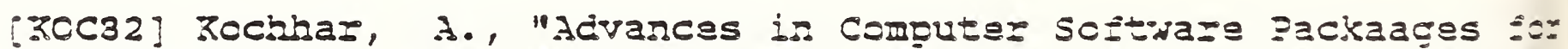

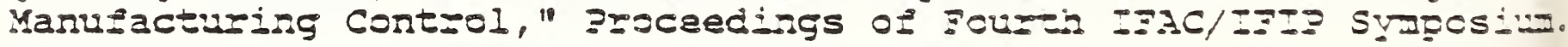

[CRI35] KISisamu thy, ?., Semantic Association Mcdel,
"A Data Minguiatior Langrage for ise SAY*," Masters thesis, coliege di 
Engineezing, University or Flordia, Gaissvilie, İ, 1985.

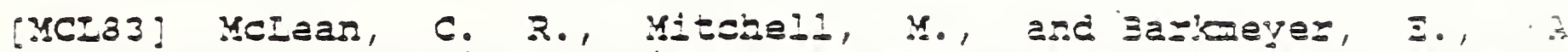

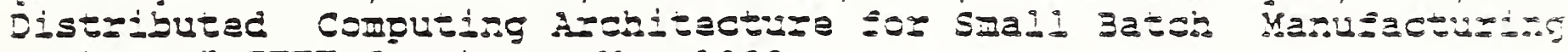
systems," IIIE Spectzim, May 1983.

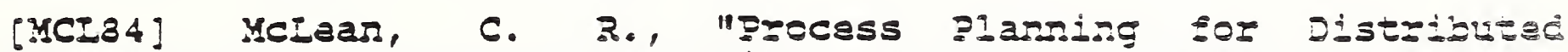

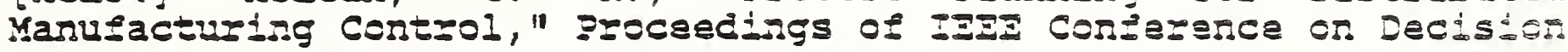
and Control, Las Vagas, $N \nabla$, Dec 12-14, 1984.

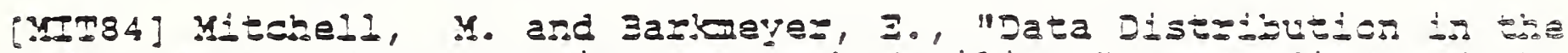

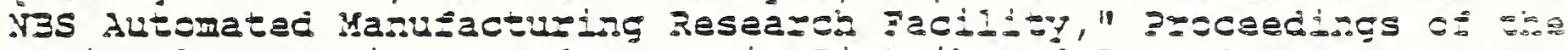

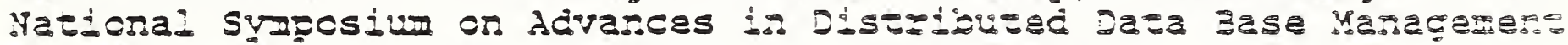

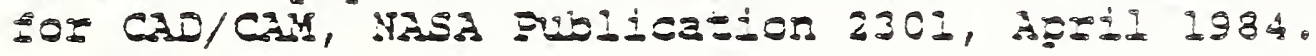

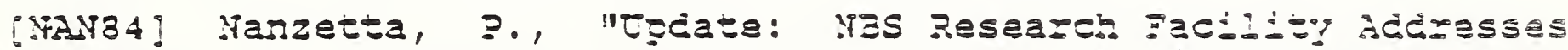

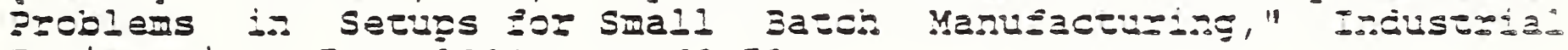
Es.ginesring, Jure ig84, sp. 58-73.

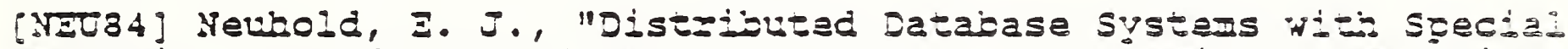
Emohasis TOwazd FOREI," IPAD II, JYoc. CI a Masioraq symeosiu, NASA Conference pubication, 220 .

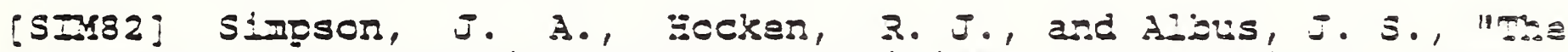

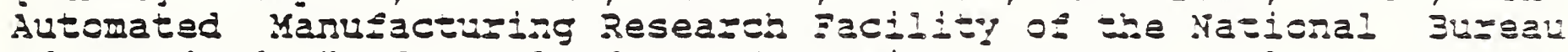
of stardards," jouzal of Marufacturise systems, iol. I, io. I, 1982 .

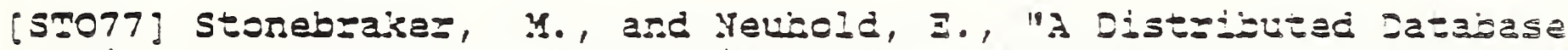

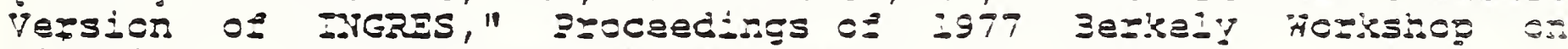
Distributed Dasa Management and Computer Yeziczls.

[SE83] Si, Stanley "SAM\#: A semartic Association Gorgozata ard Scientilie-statisticai Dazabases," Sciences, $\forall 01.29,1983$ No. $13:-199$.

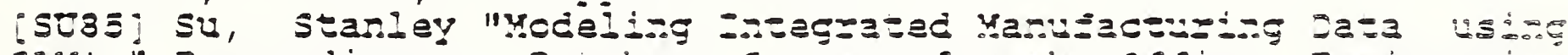

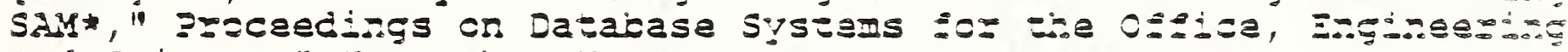

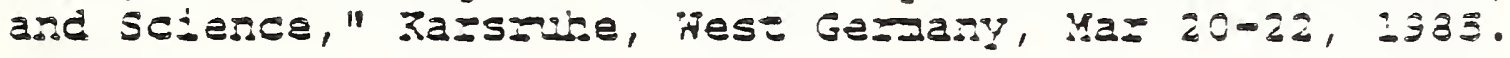

Medel Es:

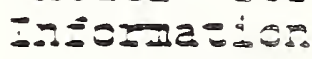

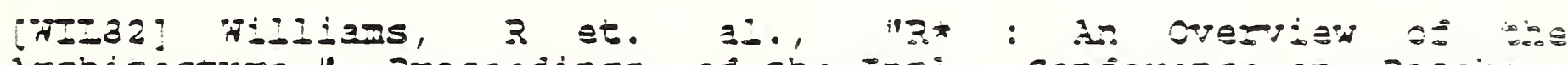

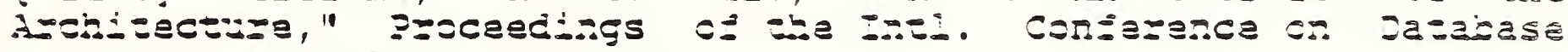
Systems, Jezisalem, Jüe 1932.

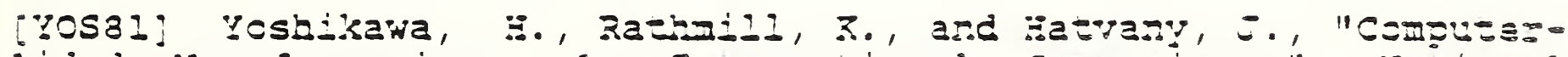

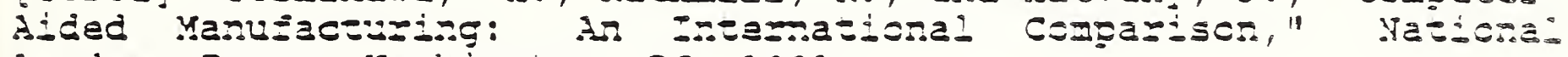
Acacemy Eress, Hashingesn, LC, les?. 


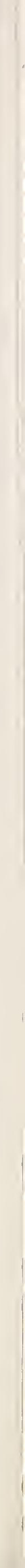




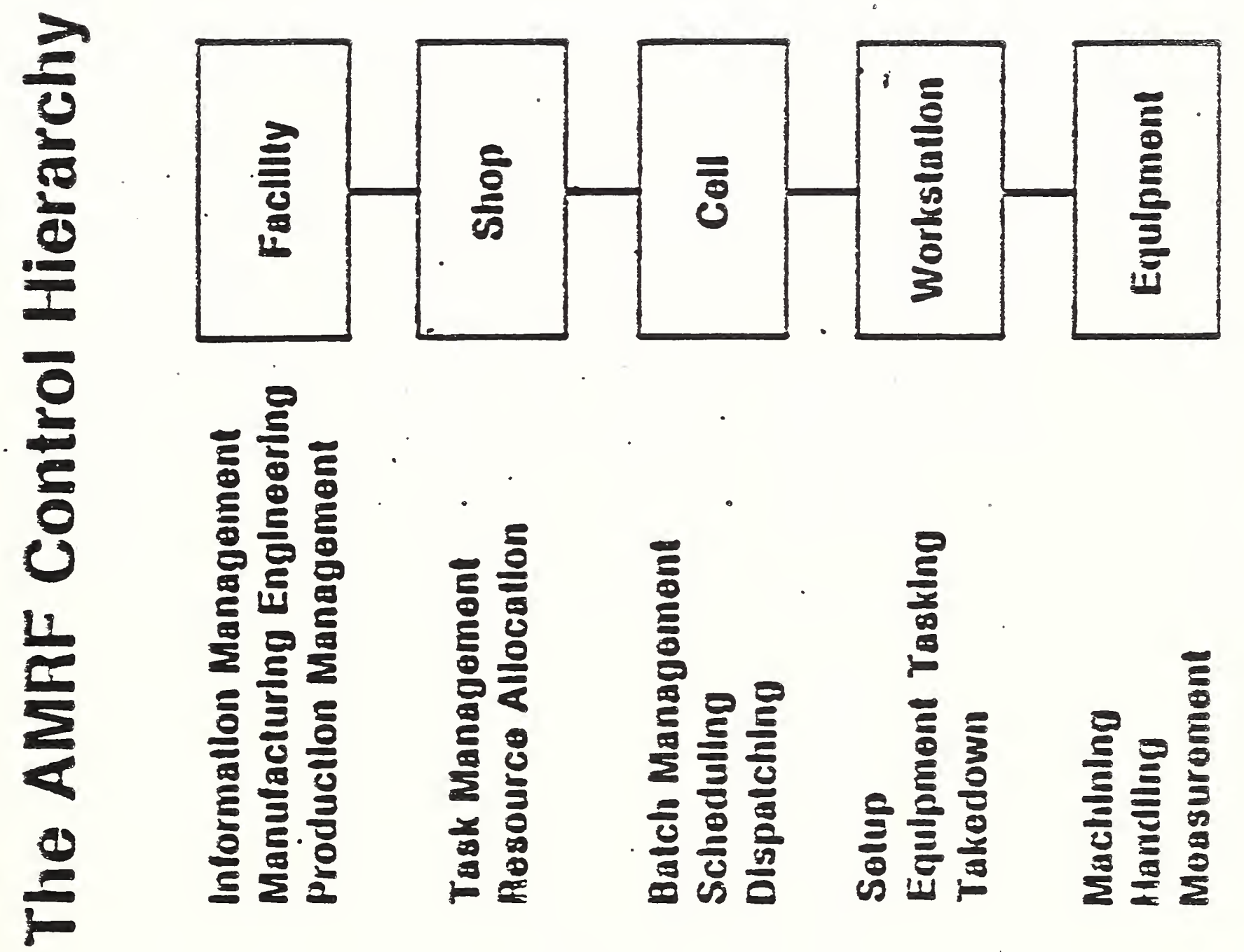




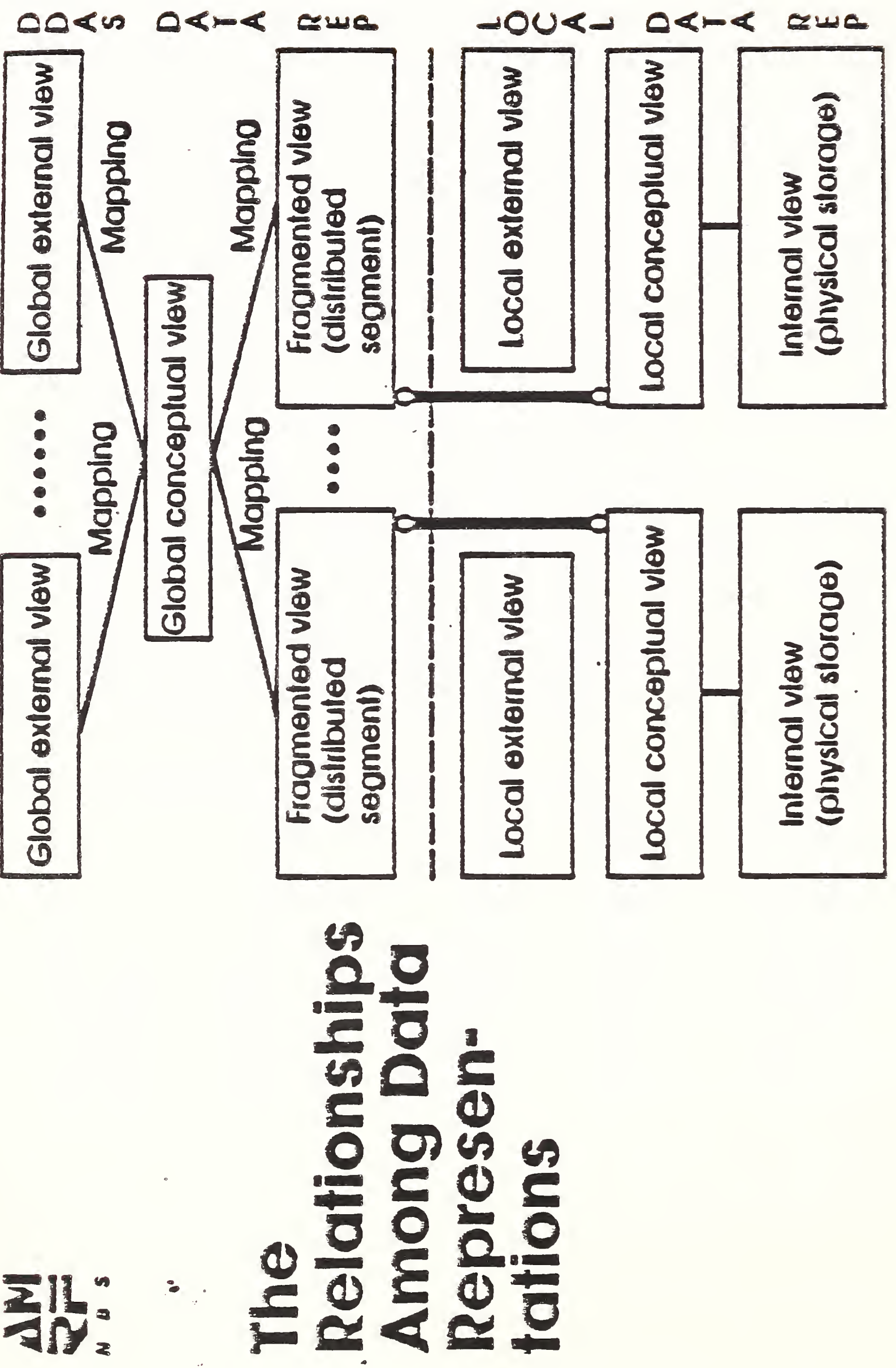



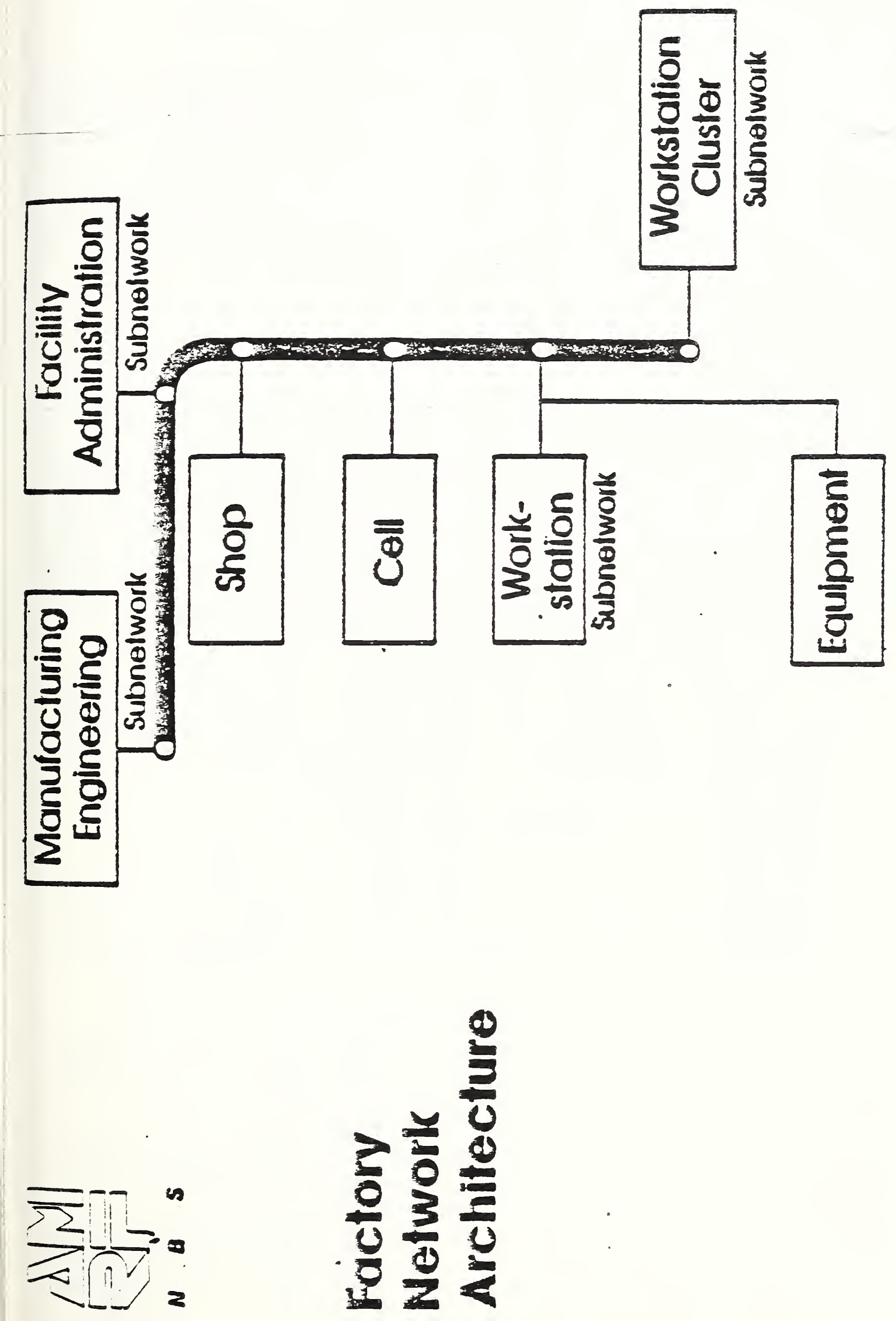


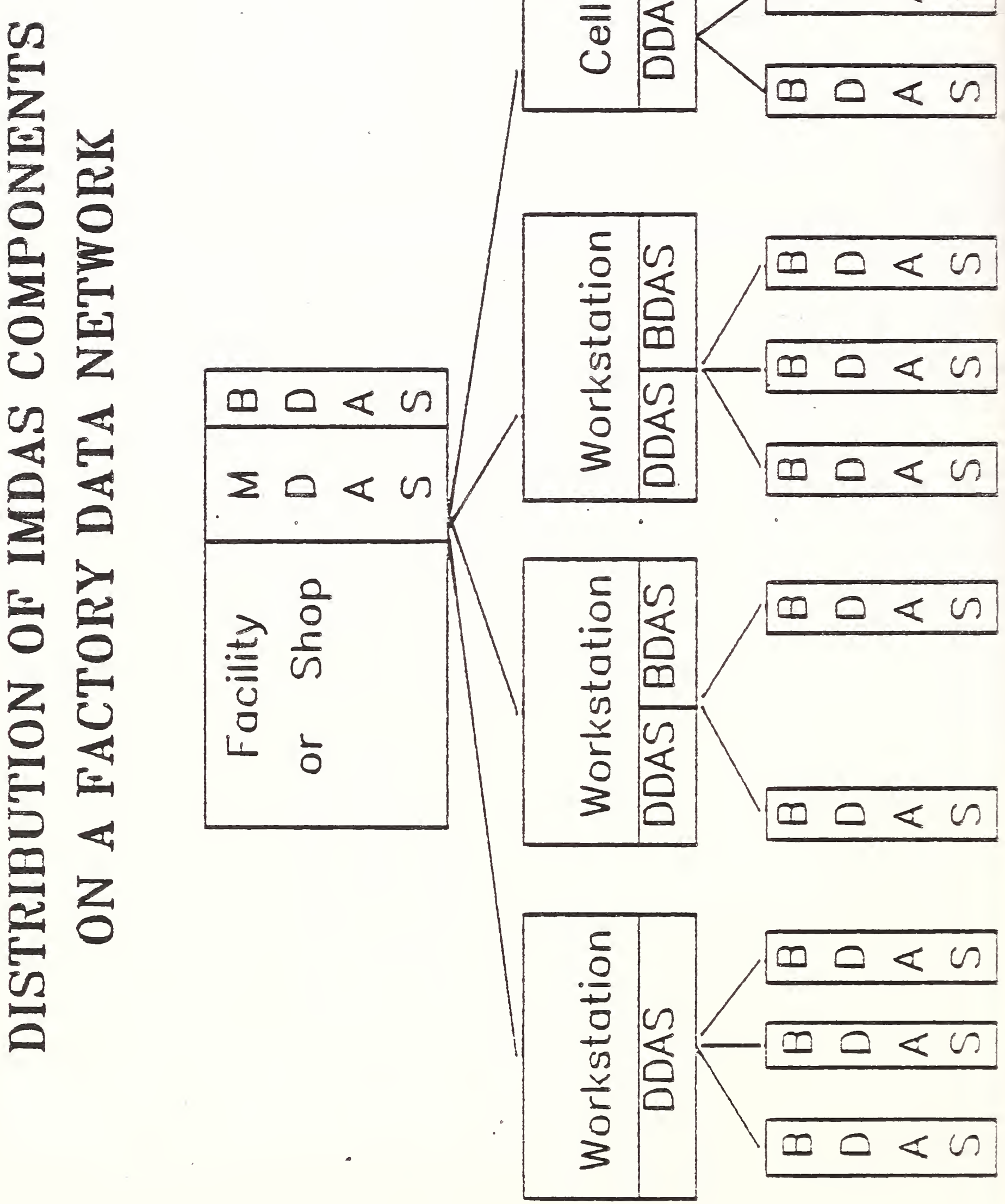




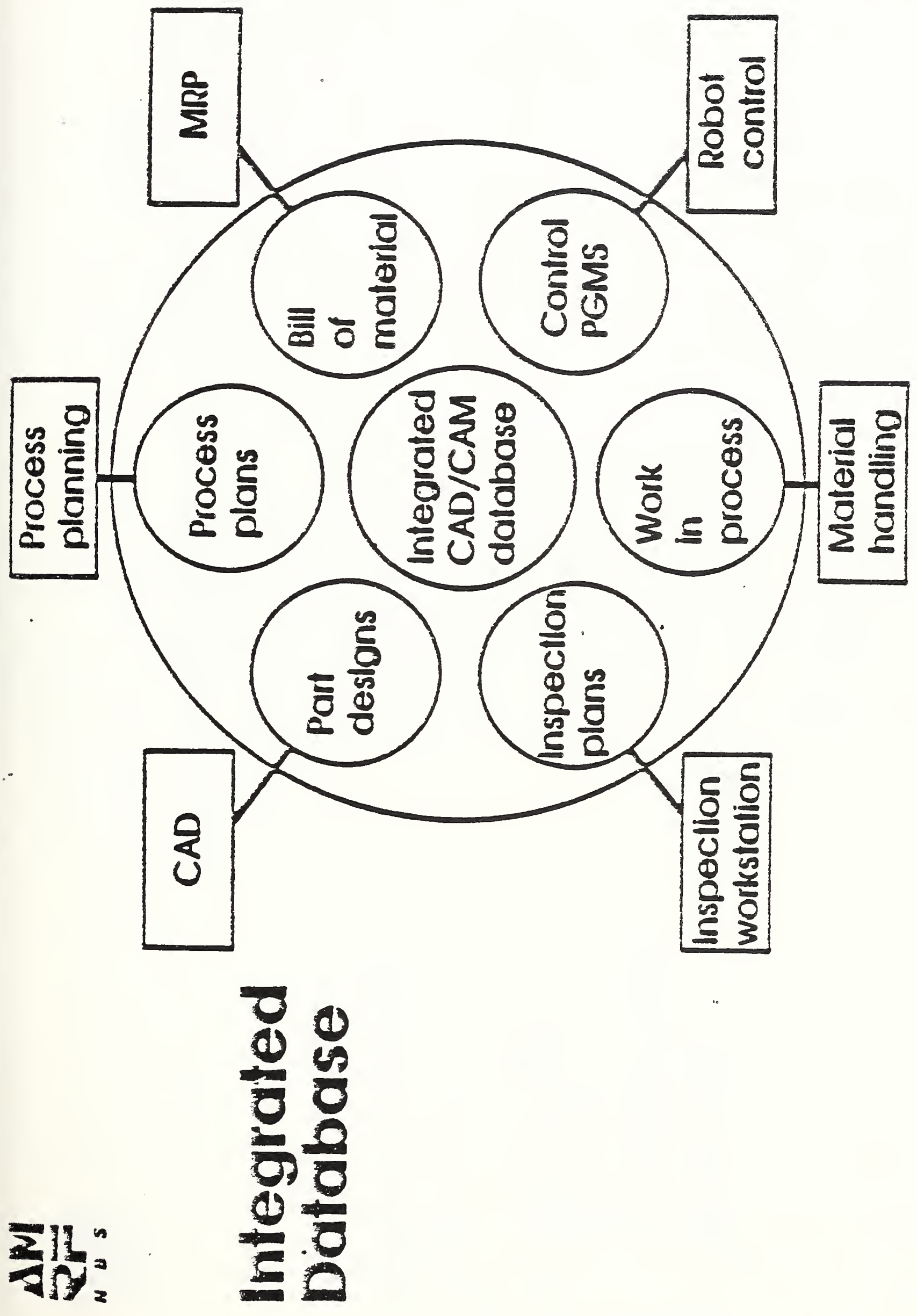



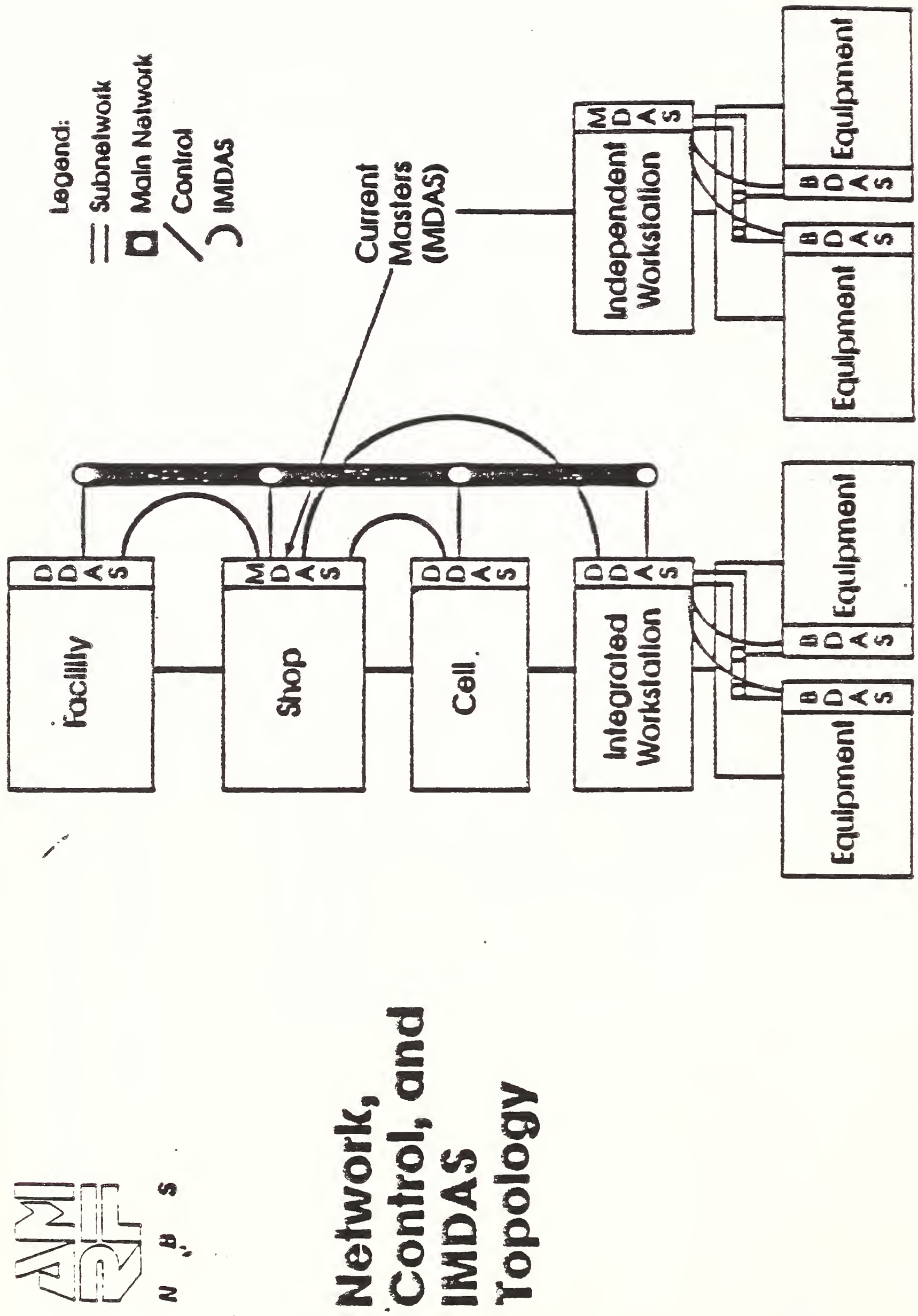

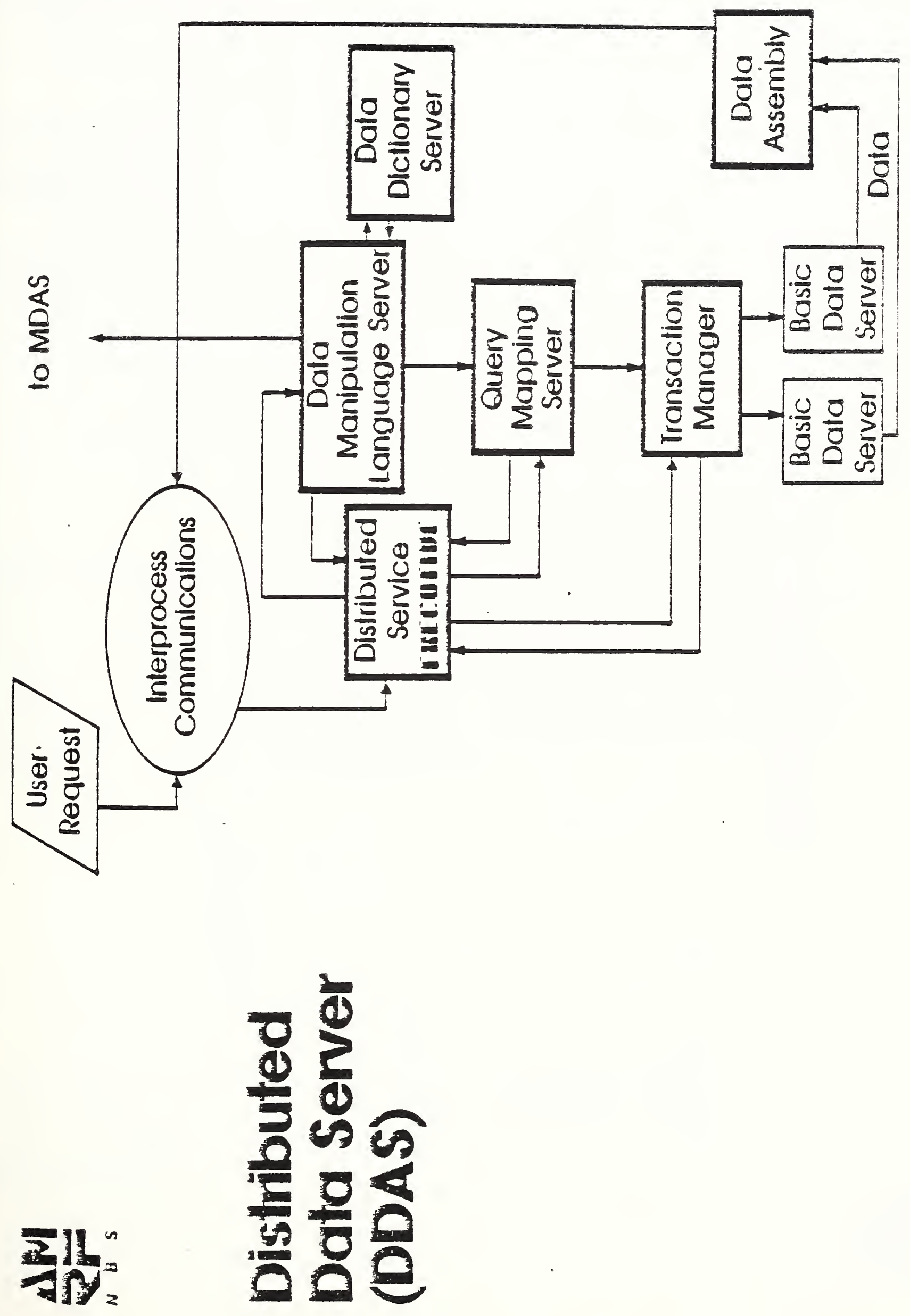


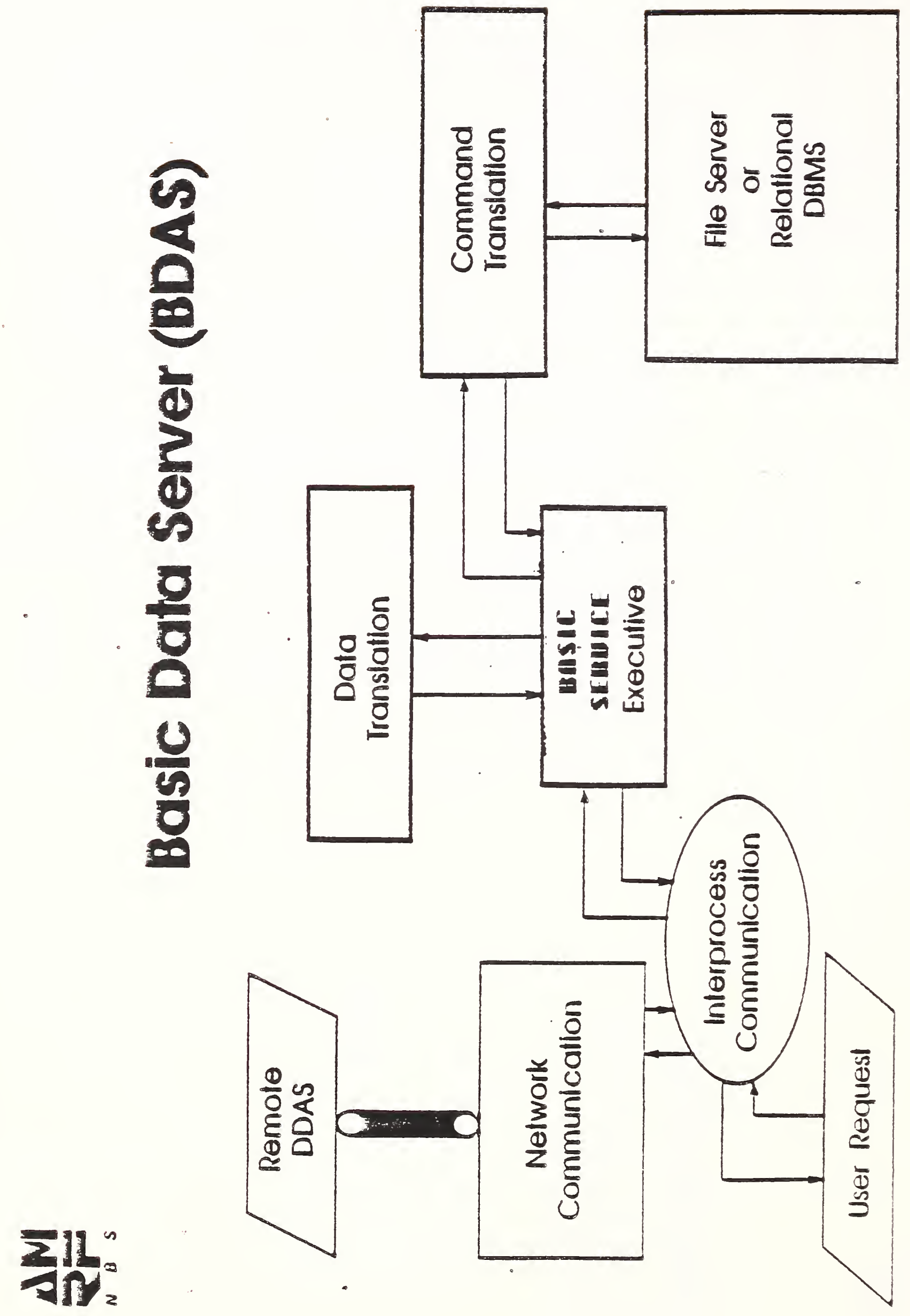




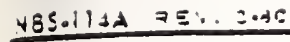

-.5. $=50 T .2=5 \mathrm{SMM}$.

BIBLIOGRAPHIC OATA

SHEET ENe - si:ucisonsi

\begin{tabular}{|c|c|c|}
\hline $\begin{array}{l}\text { PU BL:CAT:CN OR } \\
\text { REYCRT YC. } \\
\text { Y }\end{array}$ & 3. Periopming Spzar. ₹ zeor: Vo & 3. 3.jellis:16n za:s \\
\hline & & \\
\hline
\end{tabular}

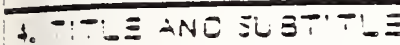

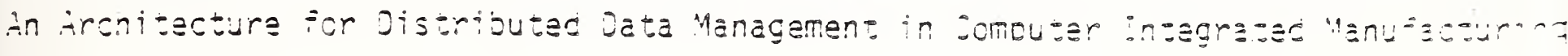

¿. AUTHOR(S) Edward Barkmeyer and Mary Mitcheli (NBS), Krishna ?. Mikki i neni, Stanley Y. U. Su, and Herman Lam 'Univ. of Florida)

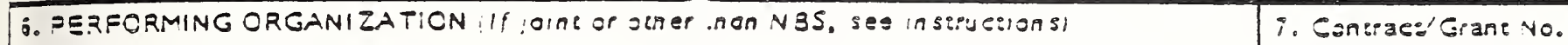

MATIONAL BUREAU OF STANOAROS

DEPARTUEHT OF COYMERCE

HASHINGTOH, O.C. 20234

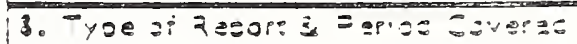

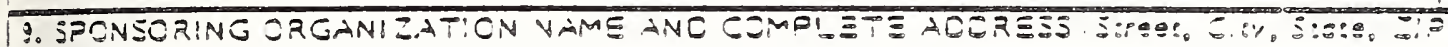

iletiona? Jureau of Stancares

Zuilding 220, Rocm 3-229

Gatithersourg, idaryiand 20890

BQ. SUPPLEMENTARY NOTES

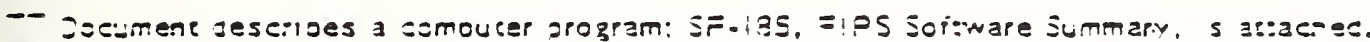

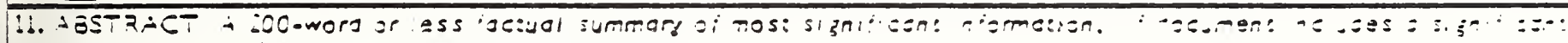

zisliczrcony or itcergiure survey. nencion is repal

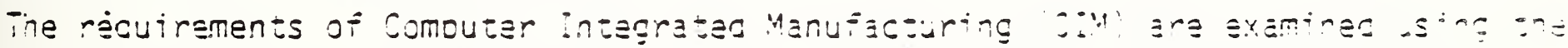

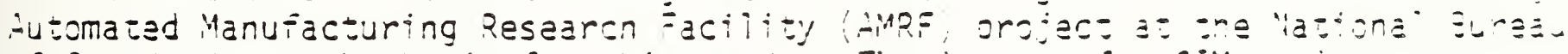

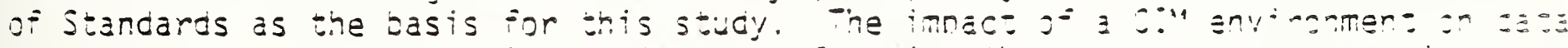

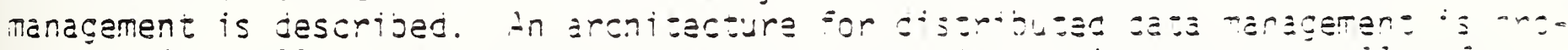

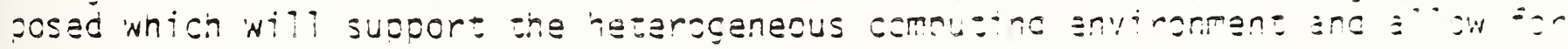
auzonomous coeration of nanuiacuring celis.

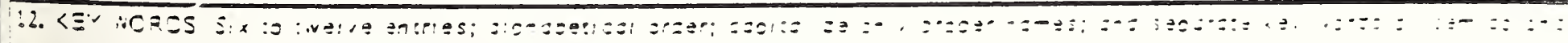

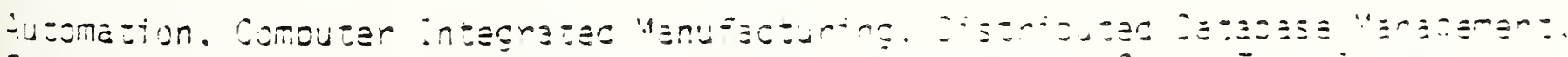

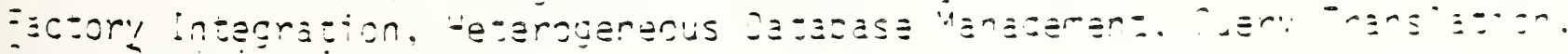

\section{:}

jar., $-0-a j=-i a n$,

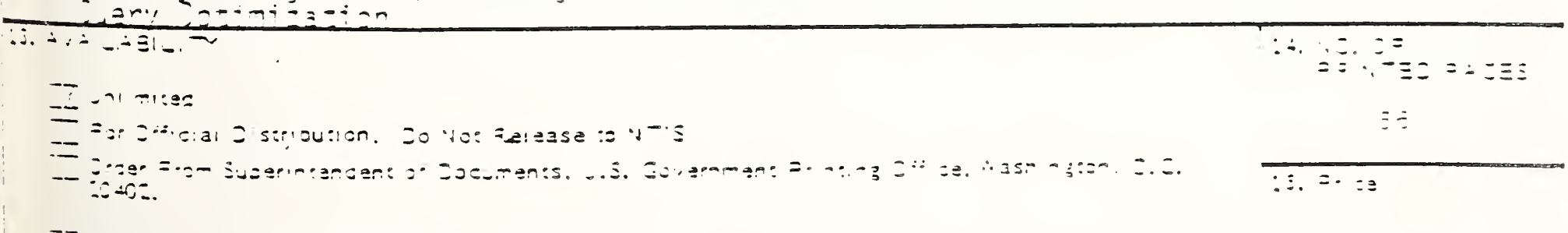

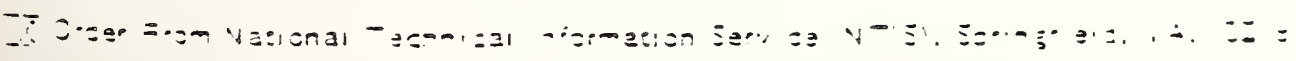




